\title{
MINERALOGY AND PETROGRAPHY OF PERMIAN ROCKS IN THE CENTRAL OKLAHOMA AQUIFER
}

By George N. Breit ${ }^{1}$, Cyndi Rice ${ }^{1}$, Ken Espositol, and Jamie L. Schlottmann ${ }^{2}$

U.S. Geological Survey

Open-File Report 90-678

This report is preliminary and has not been reviewed for conformity with U.S. Geological Survey editorial standards and stratigraphic nomenclature

${ }^{*}$ Use of trade names is for descriptive purposes only and does not imply endorsement by the U.S. Geological survey

1 U.S. Geological Survey, Branch of Sedimentary Processes, Box 25046 MS 916 Denver Federal Center, Denver, Colorado 80225

2 U.S. Geological Survey, Oklahoma District Water Resources Division, Broadway Executive Park, Bldg. 7, 202 NW 66th Street, Oklahoma City, Oklahoma, 73102 


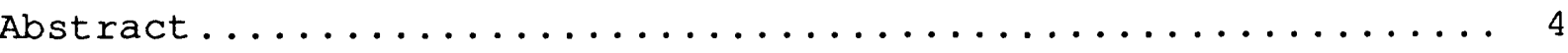

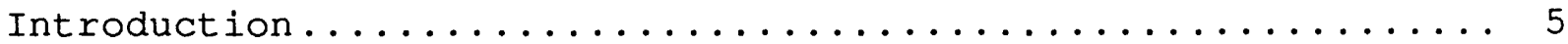

Description of the Central Oklahoma aquifer........... 6

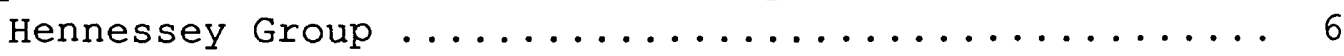

Garber Sandstone and Wellington Formation ........ 9

Chase, Council-Grove, and Admire Groups .......... 9

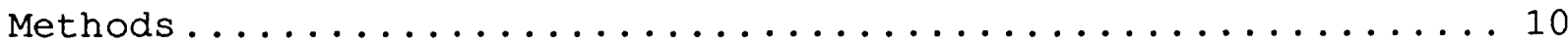

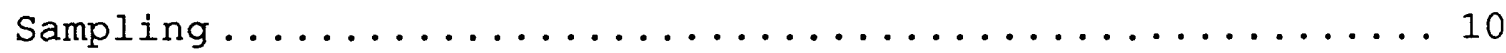

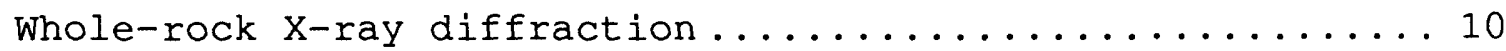

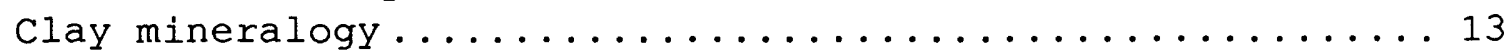

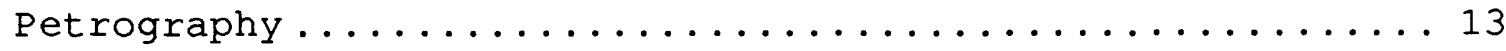

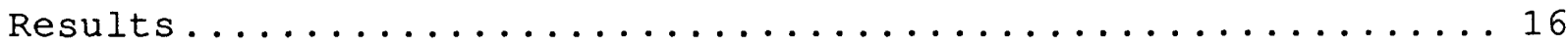

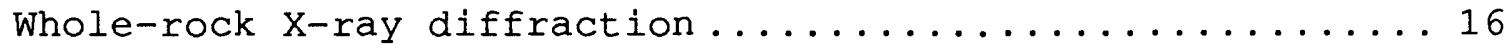

Clay-size fraction mineralogy ................. 18

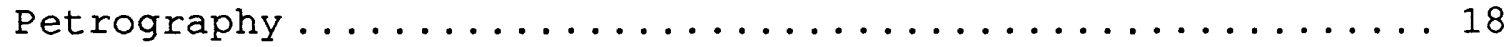

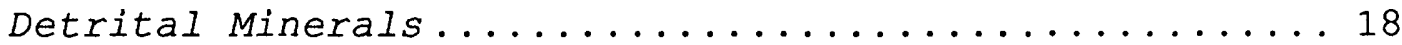

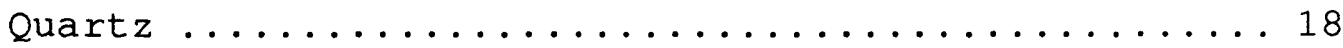

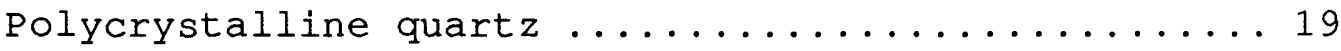

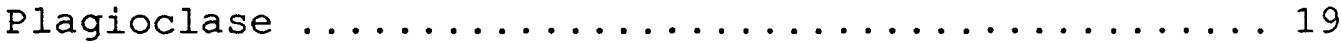

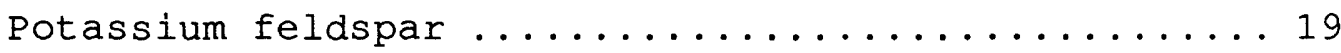

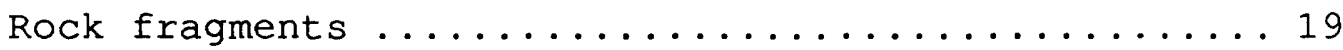

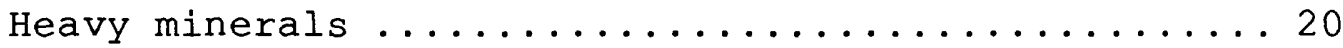

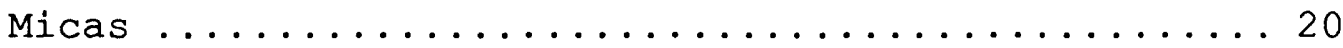

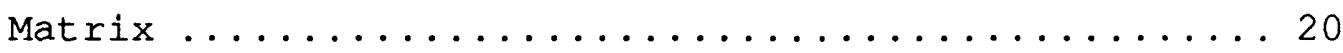

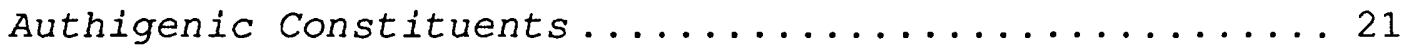

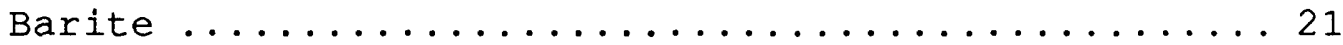

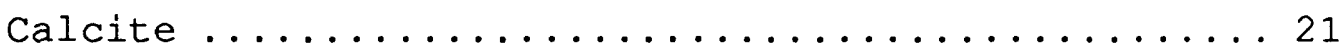

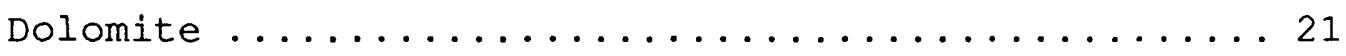

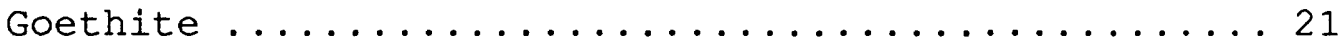

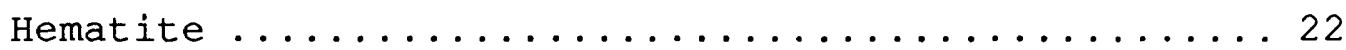

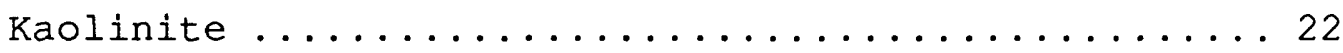

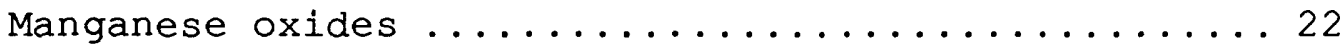

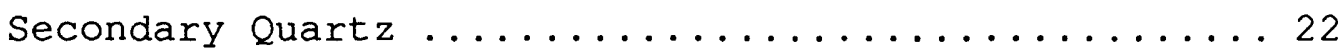

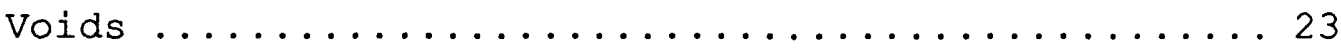

$\mathrm{x}$-ray diffraction vs. point count results ............23

Constituents of the rocks with large contents of NOTS ... 23

Summary and Future Work....................... 24

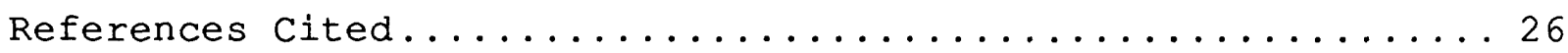




\section{List of Tables}

Table 1 Location of test holes cored for this study........ 11

Table 2 X-ray diffraction peaks used for mineralogical

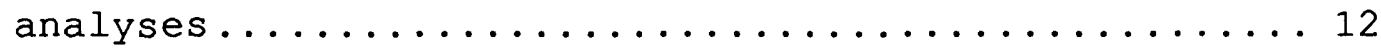

Table 3. Average abundances of major constituents as estimated by $x$-ray diffraction................ 14

Table 4. Mean volume abundances of major constituents of sandstones determined from point count results..... 17

Table 5 Recognized residences of NOTS and other transition

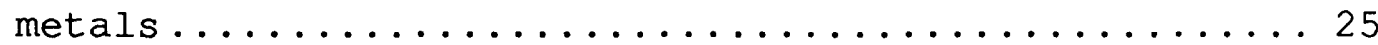

\section{List of Figures}

Fig. 1. Location of the Central oklahoma aquifer and test holes cored for this study............... 7

Fig. 2. Generalized geologic map of Central oklahoma.......8

\section{List of Appendices}

App. 1. Results of whole-rock X-ray diffraction analyses ... 28

App. 2. Clay mineralogy results ................. 35 App. 3. Brief descriptions of rock samples used for thin

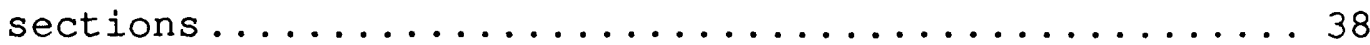

App. 4. Results of point count analyses of thin sections ... 45 


\title{
MINERALOGY AND PETROGRAPHY OF PERMIAN ROCKS IN THE CENTRAL OKLAHOMA AQUIFER by
}

George N. Breit, Cyndi Rice, Ken Esposito, and Jamie L. Schlottmann

\begin{abstract}
Permian rocks of the Central Oklahoma aquifer from nine cored test holes were analyzed to determine their mineralogical composition and petrographic characteristics. Eight of the holes were sited in areas where ground water is known to contain concentrations of arsenic, chromium, selenium, or gross residual-alpha-particle activities that exceed public drinking water standards; the nineth hole is located in an area of generally good water quality. The Permian clastic sedimentary units sampled by the test holes included 1) the Hennessey Group, 2) the Garber Sandstone and Wellington Formation, and 3) the Chase, Council-Grove and Admire Groups. Whole-rock mineralogy was determined for 196 samples; 70 samples were analyzed for clay mineralogy and 160 thin sections were point counted.

Sandstones in the aquifer are quartz arenites to sublitharenites. Quartz and illite-rich clays are the dominant detrital constituents. Plagioclase, dolostone, potassium feldspars, chert, metamorphic rock fragments, and chlorite are minor detrital phases. Common authigenic minerals in the rock include barite, calcite, dolomite, goethite, hematite, kaolinite, and quartz as overgrowths. All of the units sampled have similar compositions, although the core from the test hole sited in an area of good water quality lacked dolomite, chlorite, and plagioclase. Results of these analyses will be used in future reports to describe and interpret rock-water interaction within the aquifer.
\end{abstract}


Beginning in 1986, the Congress has appropriated funds annually for the U.S. Geological Survey to test and refine concepts for a National Water-Quality Assessment (NAWQA) Program. To develop the basic techniques needed to meet the goals of a full-scale program, seven pilot projects were initiated to study three major ground-water systems and four major surface-water systems. The long-term goals of the program are as follows:

(1) Provide a nationally consistent description of current water-quality conditions for a large part of the Nation's surface- and ground-water resources,

(2) Define long term trends (or lack of trends) in water quality, and

(3) Identify, describe and explain, as possible, the major factors that affect the observed water-quality conditions and trends.

The results of the NAWQA program will be made available to water managers, policy makers, and the public to provide an improved scientific basis for evaluating the effectiveness of water-quality management programs (Hirsch and others, 1988).

One of the ground-water systems evaluated as a NAWQA pilot project is the Central oklahoma aquifer. This aquifer was selected because it is a major source of water supplies in central oklahoma and because it has several known or suspected water-quality problems as reviewed by Parkhurst and others (1989). Among these problems are arsenic (As), chromium (Cr), and selenium (Se) concentrations that locally exceed public drinking water standards, large gross-alpha-particle activities, contamination by synthetic organic compounds and contamination by oil-field brines. In addition, large contents of uranium (U) have been detected in water from some wells.

The large concentrations of $\mathrm{As}, \mathrm{Cr}, \mathrm{Se}$ and $\mathrm{U}$ and large gross-alpha-particle activities are not obviously related to anthropogenic activity and are presumed to be the result of rock-water interaction within the aquifer. To evaluate the processes responsible for mobilization of these potentially toxic, naturally occurring trace substances (NOTS), a cooperative effort between the U.S. Geological Survey's Water Resources and Geologic Divisions was organized. Detailed studies of the water and associated rocks are in progress. This report summarizes results of one aspect of the study -- the mineralogical and petrographic study of rocks from the aquifer. Because many of the changes in composition of ground water within the aquifer are the result of reactions between rock and 
water, a characterization of solid constituents of the aquifer is important. Additional reports will describe (1) the chemical composition of the rocks (Mosier and others, 1990), geophysical log characteristics of the test holes and ground-water chemistry, and (3) lithologic variations of the cores. The detailed study of NOTS in the western part of the study unit was conducted in cooperation with the Association of Central Oklahoma Governments.

\section{Description of the Central Oklahoma Aquifer}

The Central Oklahoma aquifer (Fig. 1) extends from the Canadian River on the south to the Cimarron River on the north and to the limit of freshwater circulation, which coincides approximately with the Oklahoma-Canadian and Lincoln-Kingfisher County lines on the west. The easternmost extent of the aquifer is along the contact of the Pennsylvanian Vanoss Formation with the Permian Chase, Council-Grove, and Admire Groups. The depth of the aquifer is variable and defined by the base of freshwater $(<5000 \mathrm{mg} / \mathrm{L}$ total dissolved solids), which ranges between 100 and 1000 feet below the land surface (Parkhurst and others, 1989). The aquifer underlies all of Cleveland and Oklahoma Counties and parts of Lincoln, Logan, Payne, and Pottawatomie Counties (Fig. 1). Land-surface elevations generally decrease from west (maximum of 1410 feet) to east (minimum of about 800 feet above sea level) across the area, with major rivers discharging eastward.

Stratigraphic units that comprise the Central Oklahoma aquifer include Quaternary alluvial and terrace deposits and Permian sedimentary rocks including the Garber Sandstone, Wellington Formation, and the Chase, Council-Grove, and Admire Groups (Fig. 2). Most water within the aquifer is produced from the Garber Sandstone and the Wellington Formation. Substantial amounts of water are also contained in the Permian Chase, Council-Grove and Admire Groups, which underlie the Wellington Formation. Outside of the study unit, the permeability of these Permian rocks decreases. The petrographic and mineralogical study described herein is restricted to the Permian rocks in the aquifer and the overlying confining layer, the Permian Hennessey Group.

\section{Hennessey Group}

The Hennessey Group is the youngest of the Permian rocks considered in this study. It is composed of massive reddish-brown mudstone with lesser amounts of orange-brown to greenish gray siltstone and reddish-brown, fine-grained sandstone. This unit has relatively low hydraulic conductivity 


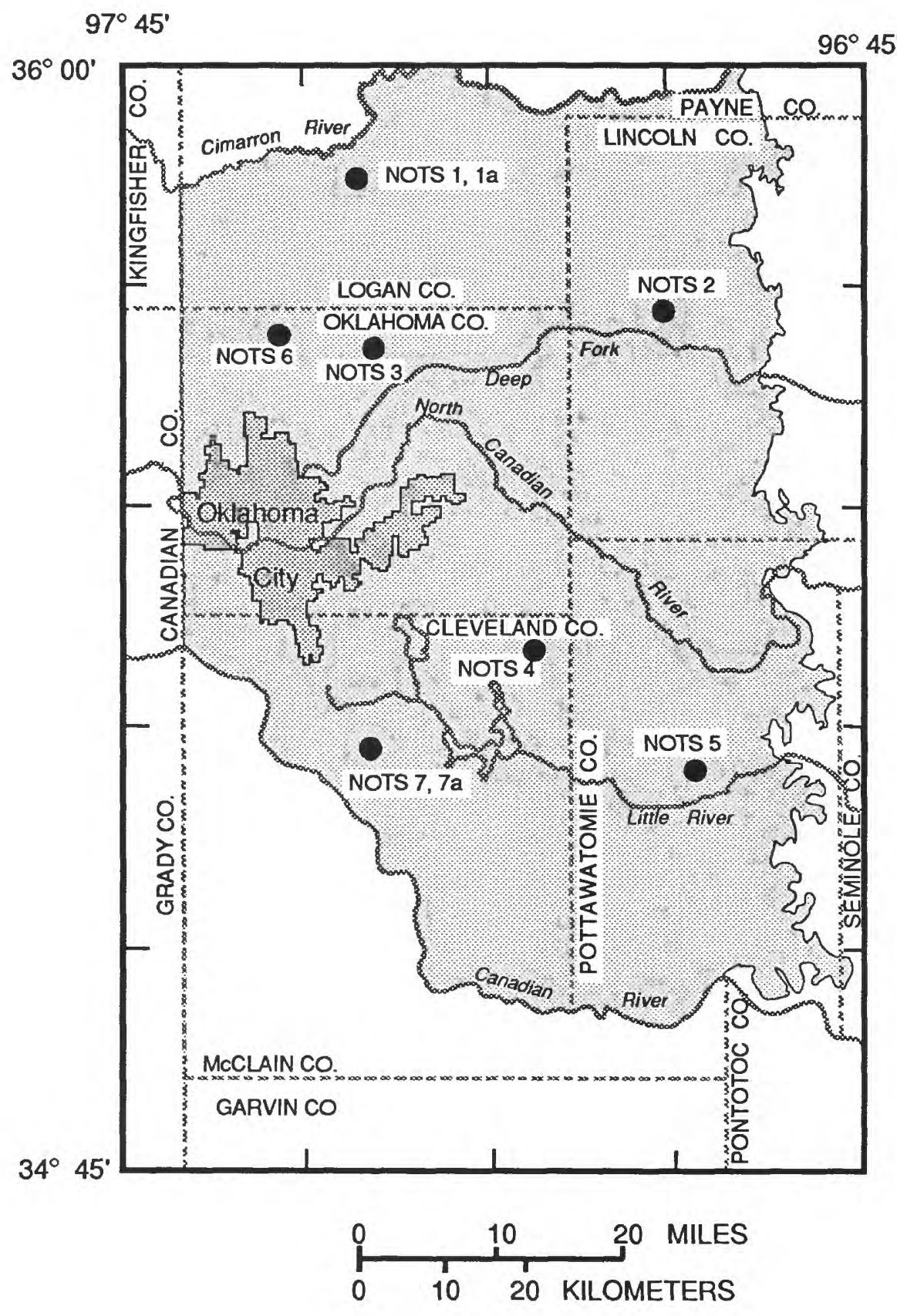

Figure 1: Location of the study unit (shaded area) containing the Central oklahoma aquifer and test wells sampled for this study. 


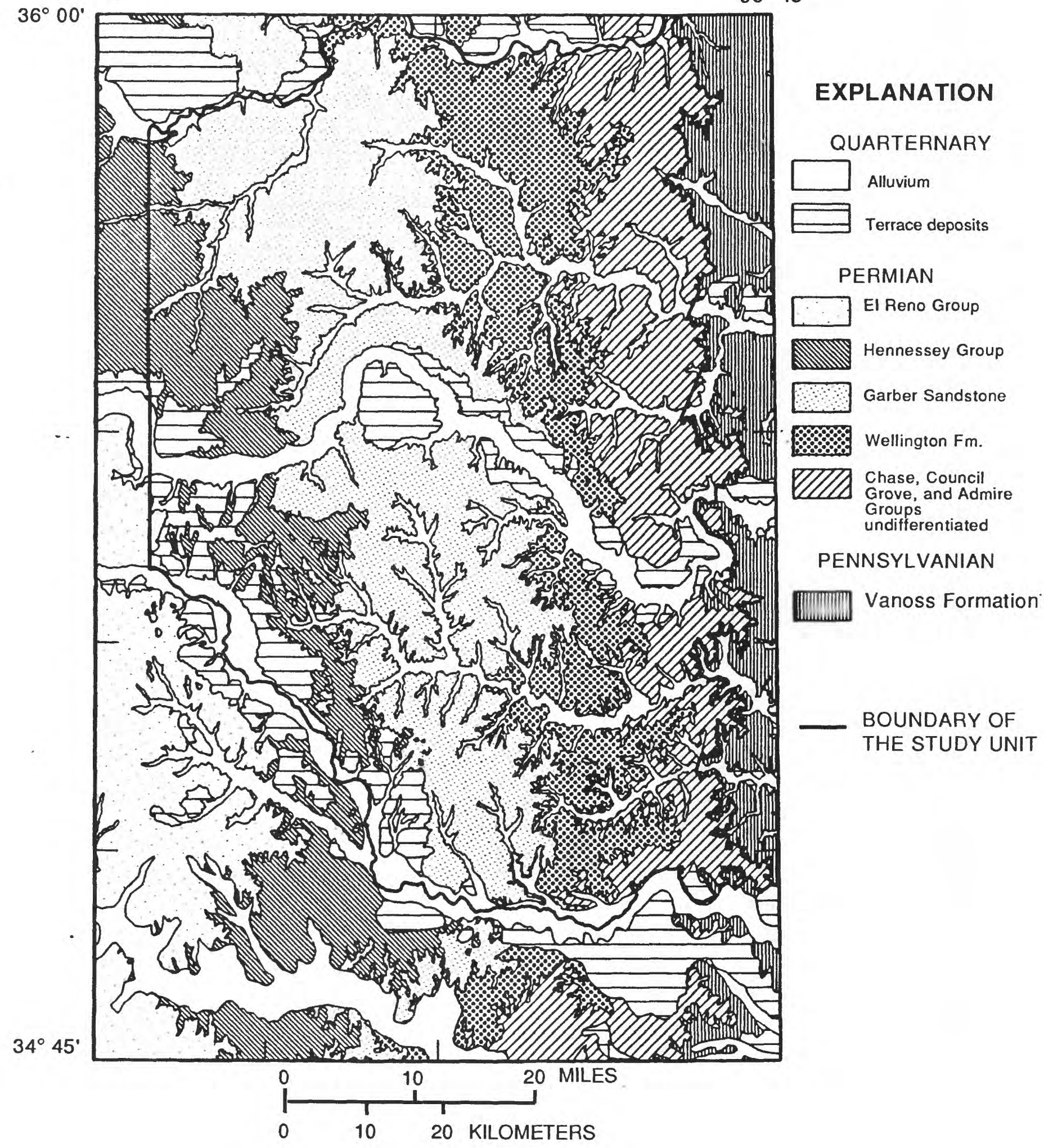

Figure 2: Geologic map of central oklahoma (modified from Bingham and Moore, 1975, and Hart, 1974). 
because of its small grain size. The Hennessey overlies the Garber Sandstone in the western 30 percent of the study area (Fig. 2); it has been removed by erosion from the remainder of the area.

Garber Sandstone and Wellington Formation

The Garber Sandstone and Wellington Formation are lithologically similar and are difficult to distinguish in subsurface (Carr and Marcher, 1977). For this reason, past aquifer studies generally have combined the two units into one geohydrologic unit named the Garber-Wellington. The Garber-Wellington sequence consists of lenticular beds of cross-bedded, fine-grained sandstone interbedded with siltstone, mudstone and local mudstone- and dolostone-pebble conglomerate. Cumulative total thickness of the units ranges from 800 to 1000 feet. The Garber-Wellington is truncated to the east by erosion.

\section{Chase, Council-Grove and Admire Groups}

The Chase, Council-Grove and Admire Groups are not differentiated in this report. They consist of reddish-brown cross-bedded, fine-grained sandstone, mudstone, and minor mudstone-, chert-, and carbonate-pebble conglomerate. The total thickness of these rocks ranges from 300 to 600 feet. Overall, these units appear similar to the overlying Wellington Formation. The three groups were formerly known as the Pennsylvanian Oscar Group (Bingham and Moore, 1975).

The Permian units in the aquifer dip very shallowly (50 feet/mile) to the west-southwest. They were deposited in marginal-marine and fluvial environments with thickened sections deposited westward toward the Anadarko basin. Detritus probably originated from sedimentary rocks deformed by the Arbuckle and Ouachita uplifts to the south and southeast (MacLachlan, 1969). Exposed rocks in these uplifts included Pennsylvanian and older Paleozoic sedimentary rocks comprised of shale, limestone, sandstone and chert. The contribution to Permian sediments from the Precambrian igneous and metamorphic rocks that comprise the core of the modern Arbuckle Mountains was minor.

The purpose of the mineralogical and petrographic study described herein was to determine the composition of rocks in the aquifer. Through systematic and detailed study, we intend to identify variations in the composition of the aquifer that reflect reaction of the water with solid constituents, and identify the phases containing the anomalous contents of As, $\mathrm{Cr}$, $\mathrm{Se}$, and $\mathrm{U}$. 


\section{METHODS}

\section{Sampling}

Nine test holes were cored at various locations in the aquifer (Table 1). One of the holes was sited in an area of generally good water quality (NOTS 4); the remaining eight were sited in areas known to have large concentrations of one or more of the potentially toxic metals (Fig. 1). Water samples were collected from 1 to 8 water-producing sandstone intervals within seven of the test holes and were chemically analyzed. The core material from eight of the test holes was split and then sampled at intervals bounded by visible lithologic and diagenetic changes for chemical analysis and petrographic study. Note that the numbering scheme for X-ray diffraction samples (Appendix 1) is distinct from the numbering system used in the identification of thin sections (Appendix 3).

\section{Whole-rock $x$-ray diffraction}

Some of the rock samples collected for chemical analysis (Mosier and others, 1990) were analyzed by X-ray diffraction (XRD) to determine their whole-rock mineralogy. These 196 samples were selected by lithology so that the relative abundances of lithologies intersected by each test hole were accurately represented. Thus, the average of the XRD results could be used to approximate the mineral composition of the total interval sampled by each test hole. The samples were ground to -250 mesh and some samples were ground with a known weight of potassium chloride (KCl). $\mathrm{KCl}$ was used as an internal standard. Packed powder mounts were prepared and scanned at $1^{\circ}$ $2 \theta /$ minute using $\mathrm{Cu} \mathrm{K}_{\alpha}$ radiation generated by a Philips XR-2000. The goniometer used for scanning was equipped with a graphite monochromater. Diffraction patterns were recorded at $2^{\circ} 2 \theta$ /inch from 4 to $44^{\circ} 2 \theta$.

Peak heights or peak areas (Table 2) were measured off the chart output and used to estimate the abundance of major mineral constituents. Peak area was estimated by multiplying the peak height by the half-width. Eight synthetic standards composed of varying weights of albite, calcite, chlorite, dolomite, hematite, illite, kaolinite, and quartz were used to define semiquantitative calibration curves for the major minerals. Because the abundances of chlorite and $\mathrm{K}$-feldspar in the samples were consistently low, only presence or absence of these minerals was noted. Although the diffraction characteristics of minerals used in preparing the standards are different from 
Table 1: Location and description of test holes cored for this study. (*, NOTS la was drilled next to NOTS 1 , samples from NOTS 1 were not studied; NOTS $7 a$ was drilled next to 7).

\begin{tabular}{|c|c|c|c|c|c|}
\hline $\begin{array}{l}\text { Test } \\
\text { Hole }\end{array}$ & & Latitude & Longitude & $\begin{array}{l}\text { Total } \\
\text { Depth }\end{array}$ & $\begin{array}{l}\text { Geologic Unit (s) } \\
\text { Sampled }\end{array}$ \\
\hline NOTS & 1 & $35^{\circ} 51 \cdot 20^{\prime \prime}$ & $97^{\circ} 25^{\prime} 00^{\prime \prime}$ & 272 & Garber Sandstone \\
\hline NOTS & $1 a *$ & $35^{\circ} 51 \cdot 18^{\prime \prime}$ & $97^{\circ} 25^{\prime} 00^{\prime \prime}$ & 268 & Garber Sandstone \\
\hline NOTS & 2 & $35^{\circ} 44^{\prime} 18^{\prime \prime}$ & $97^{\circ} 01 \cdot 35^{\prime \prime}$ & 277 & $\begin{array}{c}\text { Chase, Council-Grove } \\
\text { and Admire Groups }\end{array}$ \\
\hline NOTS & 3 & $35^{\circ} 40^{\prime} 12^{\prime \prime}$ & $97^{\circ} 23^{\prime} 10^{\prime \prime}$ & 195 & Garber Sandstone \\
\hline NOTS & 4 & $35^{\circ} 21^{\prime} 42 "$ & $97^{\circ} 10^{\prime} 35^{\prime \prime}$ & 291 & $\begin{array}{l}\text { Garber Sandstone and } \\
\text { Wellington Formation }\end{array}$ \\
\hline NOTS & 5 & $35^{\circ} 11^{\prime} 42 "$ & $96^{\circ} 58^{\prime} 01^{\prime \prime}$ & 238 & $\begin{array}{c}\text { Chase, Council-Grove } \\
\text { and Admire Groups }\end{array}$ \\
\hline NOTS & 6 & $35^{\circ} 42^{\prime} 08^{\prime \prime}$ & $97^{\circ} 33^{\prime} 02^{\prime \prime}$ & 587 & Garber Sandstone \\
\hline NOTS & 7 & $35^{\circ} 13^{\prime} 15^{\prime \prime}$ & $97^{\circ} 25^{\prime} 43^{\prime \prime}$ & 456 & Hennessey Group \\
\hline NOTS & $7 a \star$ & $35^{\circ} 13^{\prime} 15^{\prime \prime}$ & $97^{\circ} 25^{\prime} 42^{\prime \prime}$ & 631 & Garber Sandstone \\
\hline
\end{tabular}


Table 2: List of X-ray diffraction peaks used to estimate the abundance of minerals in whole-rock samples. Degrees $2 \theta$ for $\mathrm{Cu} \mathrm{K}_{\alpha}$ radiation. Peak area was estimated by multiplying peak height by the half-width.

$\begin{array}{lccc}\text { Mineral } & \begin{array}{c}\text { Crystal } \\ \text { Indices }\end{array} & \begin{array}{c}\text { Degrees } \\ (\theta\end{array} & \begin{array}{l}\text { Method of } \\ \text { Estimation }\end{array} \\ \text { calcite } & (104) & 29.4 & \text { peak height } \\ \text { dolomite } & (104) & 30.96 & \text { peak height } \\ \text { hematite } & (104) & 33.28 & \text { peak area } \\ \text { illite } & (020) & 19.6 & \text { peak area } \\ \text { kaolinite } & (001) & 12.3 & \text { peak height } \\ \text { plagioclase } & (001) & 13.85 & \text { peak height } \\ \text { quartz } & (100) & 20.83 & \text { peak height }\end{array}$


those of the minerals contained in the rocks, the data are still useful for comparison of relative abundances within the sample set. The whole-rock XRD results are tabulated in Appendix 1, with average compositions for each test-hole core and lithology listed in Table 3. Note that the XRD results are not normalized to a total of 100 percent because deviations may be errors in the estimation of a single phase, rather than a proportional error for all mineral constituents.

\section{Clay mineralogy}

As much as 60 percent of the solid constituents of the aquifer are clay- and fine silt-sized. To study the clay fraction, < $2 \mu \mathrm{m}$ size separations from 70 samples were prepared. A split of the crushed but not ground rock sample was suspended in distilled water and disaggregated by gently grinding with a mortar and pestle followed by ultrasonification. The clay fraction was then separated by centrifugation according to the procedure outlined in Jackson (1969). Initially, two size fractions were prepared, 0.5 to $2 \mu \mathrm{m}$ and $<0.5 \mu \mathrm{m}$. XRD results on the two size fractions detected the same minerals in both, therefore only $<2 \mu \mathrm{m}$ fractions were prepared from most samples. After the size separation, oriented slides of the clay-sized fraction were prepared using the procedure of Drever (1973). Portions of selected clay-sized fractions were saturated with sodium, potassium or magnesium prior to making an oriented mount. The ion saturation was used to aid in identifying mixed-layer clay minerals. All samples were treated with ethylene glycol overnight at $50^{\circ} \mathrm{C}$ prior to XRD. Some of the oriented mounts were also analyzed by XRD after they were air dried, treated with glycerol, or heated to $450^{\circ} \mathrm{C}$. Because of the range of different clay minerals in all samples, estimation of the abundance of the clays was not attempted and only qualitative results are presented. Results of the clay mineral identification are tabulated in Appendix 2.

\section{Petrography}

Thin sections from 160 samples were examined to estimate the modal composition of sandstones and some siltstones. Descriptions of the rocks used for thin sections are listed in Appendix 3. The thin sections also were examined to identify alteration textures. Alteration textures, such as dissolution or precipitation, will be used in future reports to evaluate reactions between ground-water and solid constituents of the aquifer.

The thin sections were impregnated with blue-dyed epoxy and stained for potassium feldspar using sodium cobaltinitrite, as 

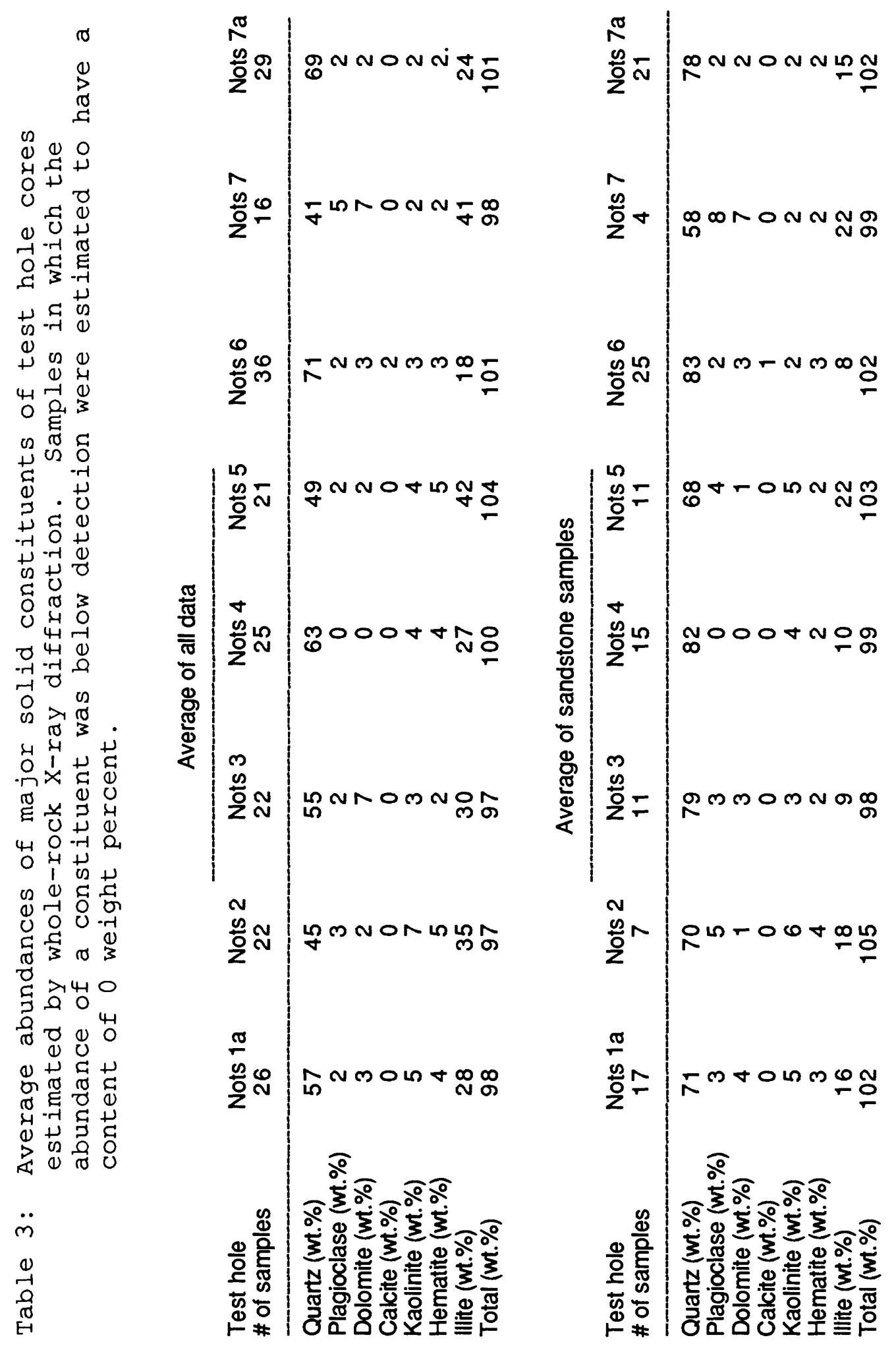


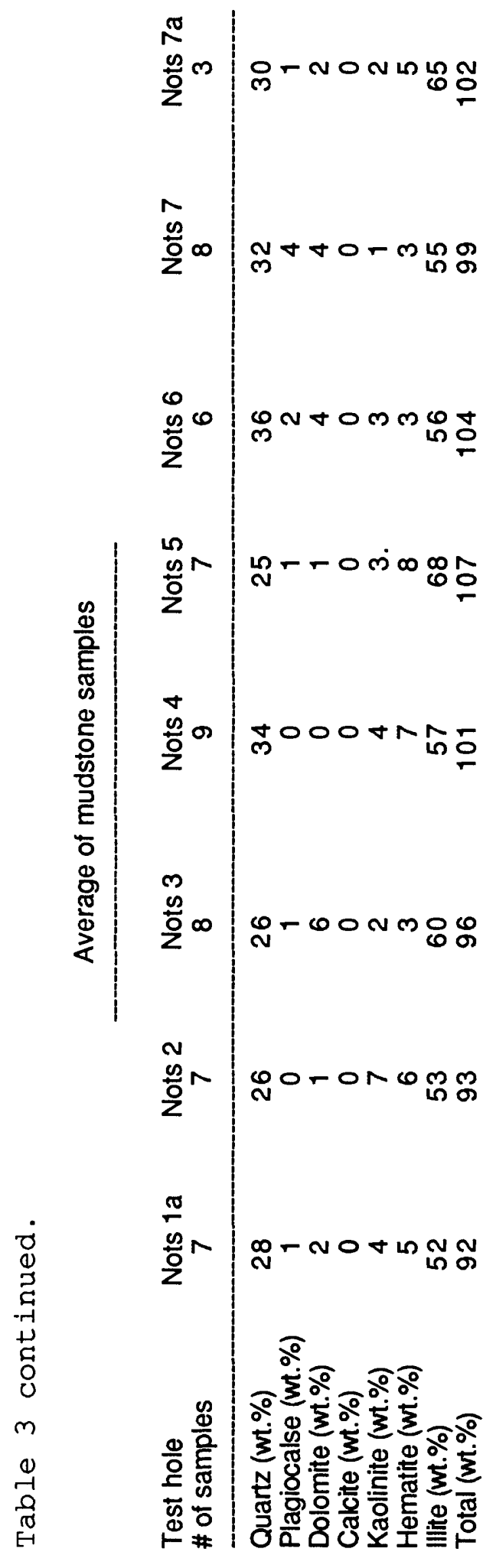


well as for carbonates using alizarin red and iron ferricyanide. The relative abundances of major constituents were estimated by counting 300 points per thin section. Counting was performed at $200 x$ or $400 x$ magnification depending on grain size. Red and green portions of the same thin section were differentiated during point counting, because of the inferred importance of redox conditions to the mobility of metals such as As, Cr, Se, and $U$. Results of point counting are tabulated in Appendix 4; averages for each test hole are listed in Table 4. Sandstones were classified using the scheme of Folk (1980); polycrystalline quartz was grouped with quartz, and chert was classified as a lithic fragment.

Many of the thin sections were prepared from rocks with an abundant clay matrix. Matrix was operationally defined for the purpose of point counting to include fine-grained aggregates of clays and quartz that fill pores and form laminae within the sandstones. In several samples, matrix material graded imperceptibly into mudstone intraclasts. Unless a clear identification of the matrix material as a clast was possible, it was counted as matrix.

Twelve polished thin sections were prepared to examine opaque minerals. Detailed observations of the textures of minerals and chemical analyses of selected phases were recorded using a scanning electron microscope (SEM) equipped with an energy dispersive spectrometer (EDS).

\section{RESULTS}

Whole-rock $x$-ray diffraction

Only small differences in mineral composition exist among the rock units sampled by the test-holes. Quartz and illite are the dominant minerals in all 8 cores (Table 3). The Hennessey Group samples (NOTS 7) have the highest content of plagioclase and contain chlorite that is consistently detectable over the length of that core. Samples from the Hennessey, Chase, Council-Grove, and Admire Groups (NOTS 2, 5 and 7) contain a higher percentage of illite than samples from the GarberWellington sequence (NOTS $1 \mathrm{a}, 3,4,6,7 \mathrm{a}$ ). Calcite and dolomite are irregularly distributed throughout the cores. Only samples from NOTS 6 contain detectable calcite in more than 30\% of the samples. Dolomite is most abundant in NOTS 3 and NOTS 7. NOTS 4, which was drilled in an area of relatively good water quality, is distinguished by the relative lack of plagioclase, chlorite and dolomite. Gypsum was not detected in any sample. 


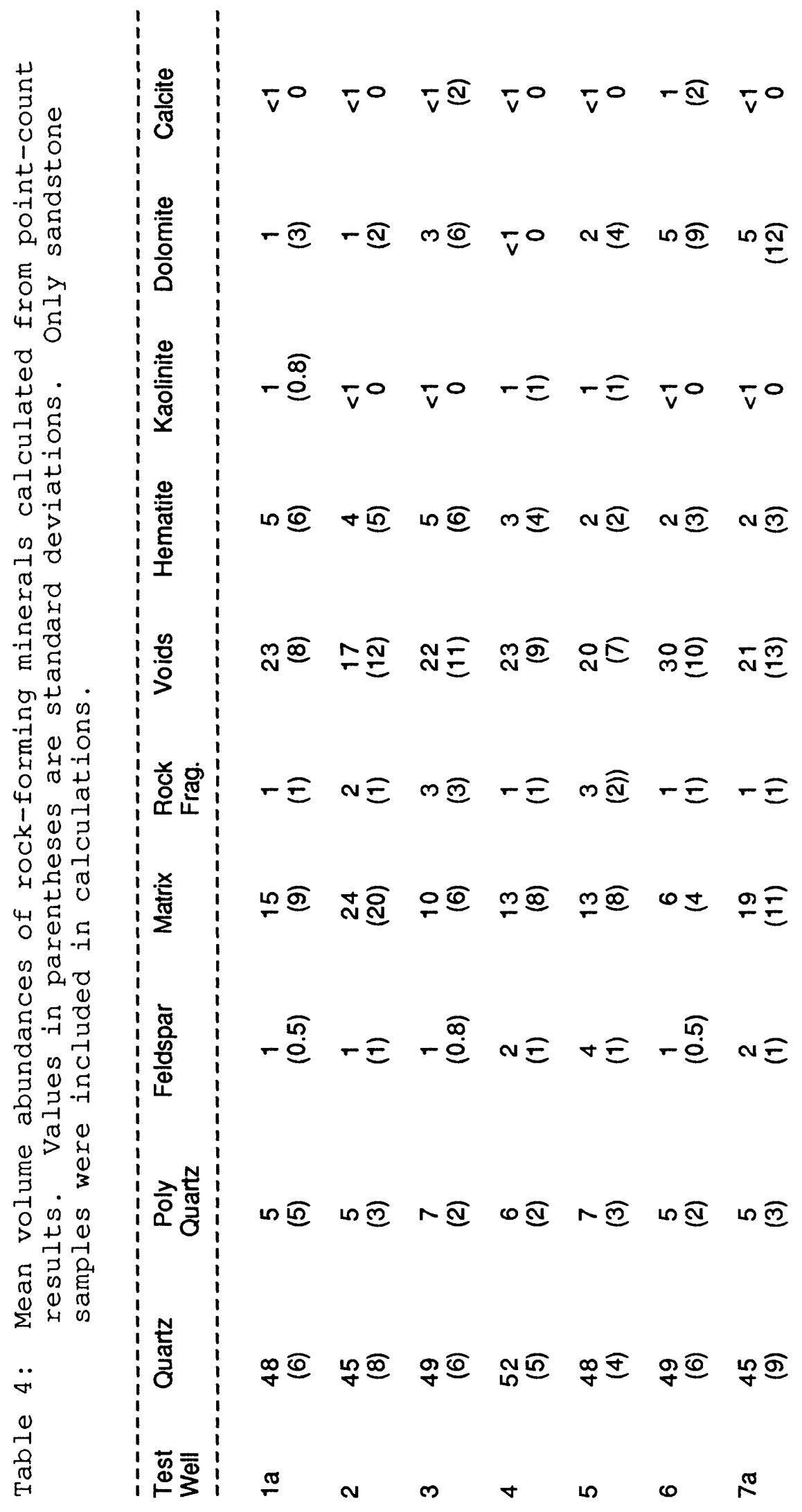




\section{clay-size fraction mineralogy}

Major components of the clay-size fractions are illite (muscovite?), kaolinite, chlorite, chlorite-smectite, illitesmectite, vermiculite, and smectite. Hematite and goethite are common minor constituents. Illite-smectite is estimated to contain approximately 20 to 30 percent expandable layers using the techniques of Srodon (1984). Some peaks in samples from NOTS 7 are suggestive of rectorite, a regularly intrastratified illite-smectite. Illite-smectite in samples from NOTS 4 and 5 is estimated to contain higher percentages of smectite layers than samples from the other cores. With the exception of the relative absence of chlorite in NOTS 4 and sparse occurrence of kaolinite in NOTS 7 (Hennessey Group), the assemblage of clay minerals is similar in all test holes and apparently independent of stratigraphic unit.

The clay-sized fractions of a few samples from NOTS 2, 3, 4 , and 5 contain a mixture of smectite and vermiculite as determined by saturation with potassium followed by magnesium saturation. After magnesium saturation, the basal spacing of a sodium saturated broad peak at $16.2 \AA$ usually shifted to a broad peak between 14 and $10 \AA$; an increase in the peak height of the illite peak at $10 \AA$ was also noted.

\section{Petrography}

The compositions of sandstones listed in Table 4 indicate that the Permian sandstones in the Central Oklahoma Aquifer are mainly quartz arenites to sublitharenites (Folk, 1980) with a significant amount of matrix. The classifications do not vary among the three stratigraphic units sampled. The sandstones are very fine to medium grained and well to poorly sorted. The composition of the detrital grains does not vary with grain size. The relatively few medium-grained sandstones are well rounded, while most of the finer grained material is subangular to angular. This angularity results both from the development of incipient quartz overgrowths and from dissolution of grains along contacts with authigenic cements. Descriptions of the rock components are presented below.

\section{Detrital Minerals}

\section{Quartz}

Most quartz grains have undulatory extinction, and approximately 30 percent have strong undulatory extinction. Fragments of vein quartz and quartz with inclusions of biotite, chlorite, or tourmaline are common in samples from all eight test holes. Quartz grains are embayed where cemented by 
hematite, manganese oxides and locally where dolomite cement is abundant.

\section{Polycrystalline quartz}

Polycrystalline quartz grains are abundant in some sandstones, ranging up to 16 volume percent. Constituent grains typically have undulatory extinction and intraclast contacts are commonly irregular, suggesting that the grains are composite metamorphic (Folk, 1980). The irregular external outlines of some of these grains are attributed to preferential dissolution of strained quartz.

\section{Plagioclase}

Two general groups of plagioclase were identified. The first type has distinct albite twinning and is commonly sericitized; the second type is untwinned, has clear interiors, good cleavage, and typically is partly dissolved. Because of the alteration and small grain size, the calcic-sodic composition of the plagioclase could not be estimated by optical techniques. Rare grains of myrmekite and perthite were also observed.

\section{Potassium feldspar}

Orthoclase and microcline are constituents of sandstones from all cores. Extinction patterns for some orthoclase grains suggest the grains were originally part of zoned crystals. Optical characteristics of these feldspars were difficult to obtain because of the staining. However, several large fragments of orthoclase were identified to be biaxial positive, which is anomalous for potassium feldspars and may indicate the presence of cryptoperthite. Most grains of potassium feldspar have been partly or extensively dissolved.

\section{Rock fragments}

Chert, metamorphic, and shale(?) rock fragments and dolostone intraclasts were observed in samples from each test hole. Chert is present as well rounded grains, some of which have been extensively dissolved leaving a skeletal interior crossed by quartz veinlets. Schist fragments consist mainly of muscovite and quartz. Shale clasts were tentatively identified by their lack of silt grains, strong parallel orientation of the clay minerals and relative lack of compaction related deformation. In most sandstones, the shale fragments are green and are rimmed by dark iron-oxide coatings.

Syngenetic(?) nodules and detrital clasts of dolomite were detected in all cores. The micritic dolostone nodules range 
from $5 \mathrm{~mm}$ to several centimeters in diameter and were found mainly within mudstones. Although the majority of the nodules are micritic, some are rimmed, veined or cored with sparry dolomite. Conglomerates from several of the test holes are composed mainly of well-rounded dolomite clasts, some of which are micritic but most have been recrystallized to aggregates of sparry cement. These clasts are likely intraclasts ripped up from mudstones in which they formed. Recrystallized clasts composed mainly of sparry grains were counted as sparry cement, not as rock fragments, because the boundaries between the clasts and sparry dolomite cement were typically poorly defined and the sparry texture represents a diagenetic alteration of the clasts.

\section{Heavy minerals}

Accumulations of heavy minerals including tourmaline, zircon, epidote, martite, titanium oxides, a rare earth phosphate mineral (monazite?) and other unidentified heavy minerals were detected in thin laminae within sandstones from all test holes. Detrital iron-titanium oxide grains are rare in green sandstones where grains of relict titanium oxides are common.

\section{Micas}

Both muscovite and biotite are minor to trace constituents of samples from most of the test holes. Muscovite is ubiquitously distributed. Most muscovite grains are silt-sized or smaller, though some are as large as medium sand. Biotite is most abundant in samples from the Chase, Council Grove and Admire Groups (NOTS 2 and 5) least abundant in NOTS 6 and $7 a$. The biotite in sandstones is typically rimmed by a thick coating of iron oxide in sandstones. A few grains of green biotite were detected in matrix-rich samples and as inclusions in quartz grains.

\section{Matrix}

Pore-filling matrix is a variable mixture of silt-sized quartz, and high and low birefringent clay minerals. Based on $X R D$ results, the dominant constituent of the matrix are illitic clays. Illite is interpreted to be detrital because of textures detected with the scanning electron microscope and deformation of the matrix related to compaction of framework grains. Much of the matrix may be the result of deformation of mudstone intraclasts. Lineations in the clasts, defined by the alignment of clay minerals conform to the boundaries of adjacent detrital grains suggesting they were deformed during compaction. No 
consistent textural or mineralogical distinctions between the red and green matrix were noted.

\section{Authigenic Constituents}

Barite

Barite was found in only 2 samples (NOTS 6, 459.7'; NOTS 6, 494.8'). It occurs as elongate, clear prisms within voids that lack other authigenic minerals. Locally the aquifer is cemented by barite roses, which are readily detected in some weathered outcrops. No massive barite cement typical of the roses was detected in the test-holes.

\section{Calcite}

Calcite was detected in several samples and occurs mainly as a poikilotopic cement. The cement occurs in optically continuous patches that fill the pore space surrounding as many as 20 contiguous detrital grains. Vermicular books of kaolinite and blebs of hematite are present as inclusions within the cement. Contacts between calcite and dolomite are abrupt and irregular.

\section{Dolomite}

A significant percentage of the Permian sandstones examined are cemented by dolomite. Locally the cement is micritic, particularly within burrows(?) outlined by iron oxides, but most cement is sparry. Sparry dolomite locally cements sandstones and is dispersed in clay-rich matrix layers, particularly near dolomite conglomerates. The sparry cement commonly contains inclusions of hematite, which form pseudo-rhombic outlines within the dolomite (particularly in NOTS 1 a and 5). Energy dispersive analyses of dolomite suggest it contains a few percent of manganese.

\section{Goethite}

A few samples with yellow-brown iron oxides contain goethite detectable by X-ray diffraction, particularly in clay-sized separates. Areas of samples that contain abundant goethite, lack carbonate cements and are very friable. Examination of polished thin sections revealed that aggregates of goethite are cored by hematite. The identification of both iron oxides was verified by XRD. Goethite was not included in the point count determination because it forms relatively thin coatings on other grains and was rarely intersected during the counting process. 


\section{Hematite}

Hematite is a common constituent of most of the rocks examined and is responsible for the red and purple colors. It occurs in massive, opaque, pore-filling aggregates, as isolated blebs a few micrometers in diameter, and as sub-micrometer particles disseminated within the matrix. Hematite dispersed within the matrix was not distinguishable and was counted as matrix. SEM examination detected spherical rosettes of hematite both within dolomite and disseminated through most sandstones. In polished section, the hematite spheres have a massive metallic rim and a finely divided core that contains abundant red internal reflections.

\section{Kaolinite}

Kaolinite is ubiquitous within the aquifer's sandstones both as vermicular books, which are as large as $100 \mu \mathrm{m}$ in width, and as random aggregates that fill pore space. Partial replacement of detrital grains by kaolinite was not observed although some pore-filling aggregates have boundaries that resemble detrital grains. Thin layers of kaolinite that extend as far as a centimeter were detected in some matrix rich samples. This kaolinite fills pore space and appears to be peneconcordant with layering in the sandstone. Kaolinite is present as inclusions in dolomite and calcite.

\section{Manganese oxides}

Dendrites of manganese oxide were visible in green sandstone and mudstone intervals in most cores and in one thin section (NOTS 4, 252.1'). Manganese oxides in this sample fill pore-space between irregularly shaped detrital quartz grains along the contact of red and green argillaceous sandstones. A boxwork of manganese oxides after dolomite was detected by SEM in NOTS $689.5^{\prime}$.

\section{Secondary quartz}

Incipient quartz overgrowths were detected in most sandstone samples. Generally the overgrowths are small $(<50 \mu \mathrm{m})$ and were most easily detected using an SEM rather than a standard petrographic microscope. The overgrowths have smooth faces and lack etch or pit marks on their surfaces. Quartz overgrowths are abundant on quartz grains cemented by calcite but are absent in grains surrounded by dolomite cement. 


\section{Voids}

The sandstones in the aquifer have as much as 36 percent void space. Grains within samples that have a high percentage of void space have few grain to grain contacts. Some of the voids contain rounded remnant outlines of clay minerals that are consistent with formation of some void space by dissolution of detrital grains. The abundance of dolomite or calcite cement in some thin sections is comparable to the amount of void space in other samples. This suggests a relation between modern porosity and dissolution or precipitation of carbonate cements.

\section{$x$-ray diffraction vs, point count results}

The average estimated abundances of the rock constituents determined by XRD and point count results (after correction for void space) for all constituents are similar except for plagioclase and kaolinite. Both of these minerals are estimated to be 3 to 4 times more abundant in the XRD results as compared with point count data. The higher estimates of plagioclase abundance by XRD could be due to the difference in diffraction characteristics between plagioclase in the rocks and plagioclase used as a standard, or to misidentification of plagioclase grains during point counting. To verify the point count results, a few thin sections were carefully recounted and similar results were obtained. The generally small grain size of these sandstones may have caused misidentification of some plagioclase grains as quartz. In contrast, the XRD results failed to detect plagioclase in most samples from NOTS 4 while it was identified during point counting. Most of the plagioclase grains observed in NOTS 4 core were extensively dissolved, which could have limited detection by XRD.

The higher estimates of kaolinite by $x$-ray diffraction could reflect high contents of kaolinite within the matrix, consistent with kaolinite detected in mudstone samples (Appendix 2). Alternatively, some of the kaolinite may have become preferentially oriented during preparation of the packed powder mounts and resulted in enhanced peak intensities.

\section{Constituents of the rocks with large contents of NOTS}

Several samples were examined with the SEM and by XRD to identify residences of As, Se, $\mathrm{Cr}, \mathrm{U}$ and other transition metals in the rocks. These samples were selected because of the large concentrations of these metals detected by chemical analyses of the whole-rock samples (Mosier and others, 1990) and by observations of thin sections and core material. Many of the anomalous samples can be characterized as reduction spheroids (Hofman, 1990). Preliminary results of these examinations are 
presented in Table 5. Although the results from only a few of the reduction spheroids are listed, they are representative of the spheroids common to most of the test hole cores.

\section{SUMMARY AND FUTURE WORK}

Permian rocks that comprise much of the Central Oklahoma aquifer are mainly quartz arenites and sublitharenites with variable amounts of illite-rich matrix. All of the geologic units sampled for this study contain similar rock-forming minerals that vary only slightly in abundance among the units. Authigenic constituents of the rocks include barite, calcite, dolomite, goethite, hematite, kaolinite, and minor quartz overgrowths.

Future reports will evaluate these data in relation to the chemical composition of water produced from the aquifer and the phases that comprise the aquifer. These evaluations will focus on identification of processes responsible for mobilization of the potentially toxic metals into the ground water. Additional work to develop an understanding of the diagenetic history of these rocks is also underway. 
Table 5: Preliminary identification of residences of arsenic, chromium, selenium, uranium and other transition metals in Permian rocks of the Central Oklahoma aquifer. (Method of identification: SEM-EDS, scanning electron microscope with energy dispersive analyzer; XRD, X-ray diffraction; ?, identification uncertain).

\begin{tabular}{|c|c|c|}
\hline $\begin{array}{l}\text { Test } \\
\text { Hole }\end{array}$ & $\begin{array}{l}\text { Depth } \\
\text { (feet) }\end{array}$ & Phase \\
\hline $\begin{array}{c}1 \mathrm{a} \\
1\end{array}$ & $\begin{array}{l}65.4 \\
82.4\end{array}$ & $\begin{array}{l}\text { Arsenic } \\
\text { brown iron oxides, goethite? (SEM-EDS) } \\
\text { brown iron oxides, and pyrite (SEM-EDS) }\end{array}$ \\
\hline $\begin{array}{c}1 \\
2 \\
\text { Hennessey }\end{array}$ & $\begin{array}{c}82.4 \\
131.1 \\
\text { outcrop }\end{array}$ & $\begin{array}{l}\text { Chromium } \\
\text { brown iron oxides (SEM-EDS) } \\
\text { detrital chromite (SEM-EDS) } \\
\text { smectite? (SEM-EDS) }\end{array}$ \\
\hline $\begin{array}{l}2 \\
6 \\
6\end{array}$ & $\begin{array}{l}131 \cdot 1 \\
404 \cdot 3 \\
502 \cdot 3\end{array}$ & $\begin{array}{l}\text { Selenium } \\
\text { unidentified Cu-Se-S phase (SEM-EDS) } \\
\text { clausthalite (PbSe) (SEM-EDS) } \\
\text { native selenium (SEM-EDS) }\end{array}$ \\
\hline $\begin{array}{l}2 \\
6 \\
6 \\
7\end{array}$ & $\begin{array}{l}131 \cdot 1 \\
502 \cdot 3 \\
502 \cdot 3 \\
152.1\end{array}$ & $\begin{array}{l}\text { Uranium } \\
\text { unidentified U-Ti phase (SEM-EDS) } \\
\text { tyuyamunite? (SEM-EDS; XRD) } \\
\text { uranium-silica spheres (SEM-EDS) } \\
\text { tyuyamunite (SEM-EDS) }\end{array}$ \\
\hline $\begin{array}{l}2 \\
2 \\
5 \\
6 \\
6 \\
7\end{array}$ & $\begin{array}{l}86.4 \\
211.1 \\
120.5 \\
404.6 \\
502.3 \\
152.1\end{array}$ & $\begin{array}{l}\text { Vanadium } \\
\text { haggite (XRD) } \\
\text { haggite and volborthite (XRD) } \\
\text { haggite } \\
\text { tyuyamunite? (SEM-EDS) } \\
\text { vanadium oxides (SEM-EDS) } \\
\text { vanadium oxides (SEM-EDS) }\end{array}$ \\
\hline
\end{tabular}


Bingham, R.H., and Moore, R.L., 1975, Reconnaissance of the water resources of the Oklahoma City quadrangle, central Oklahoma: Oklahoma Geological Survey Hydrologic Atlas 4, scale $1: 250,000,4$ sheets.

Carr, J.E., and Marcher, M.V., 1977, A preliminary appraisal of the Garber-Wellington aquifer, southern Logan and northern Oklahoma counties, Oklahoma: U.S. Geological Survey Open-file Report 77-278, $23 \mathrm{p}$.

Christenson, S.C., and Parkhurst, D.L., 1987, Ground-water quality assessment of the Central Oklahoma Aquifer, Oklahoma: Project Description: U.S. Geological Survey Open-file Report 87-235, $30 \mathrm{p}$.

Drever, J.I., 1973, The preparation of oriented clay mineral specimens for X-ray diffraction analysis by a filter membrane peel technique: American Mineralogist, v. 58, p. 553-554.

Folk, R.L., 1980, Petrology of Sedimentary Rocks: Hemphill Publishing Company, Austin, Texas, $185 \mathrm{p}$.

Hart, D.L., Jr., 1974, Reconnaissance of the water resources of the Ardmore and Sherman quadrangles, southern Oklahoma: Oklahoma Geological Survey Hydrologic Atlas 3, scale $1: 250,000,4$ sheets.

Hirsch, R.M., Alley, W.M., and Wilber, W.G., 1988, Concepts for a National-Water-Quality Assessment Program: U.S. Geological Survey Circular 1021, 42 p.

Hofman, B.A., 1990, Reduction spheroids from northern Switzerland: Mineralogy, geochemistry and genetic models: Chemical Geology, v. 81, p. 55-81.

Jackson, M.L., 1969, Soil Chemical analysis -- Advanced Course, 2nd edition, 11th printing: Madison, Wisconsin, Published by the author, $895 \mathrm{p}$.

MacLachlan, M.E., 1969, Paleotectonic investigations of the Permian system in the United States, Chapter E, Oklahoma, U.S. Geological Survey Professional Paper 515-E, p. 85-92. 
Mosier, E.L., Briggs, P.H., Crock, J.G., Kennedy, D.R., Mckown, D.M., Vaughn, R.B., and Welsch, E.P., 1990, Analyses of Subsurface Permian Rock samples from the Central Oklahoma aquifer: U.S. Geological Survey Open-file Report 90-456, $65 \mathrm{p}$.

Parkhurst, D.L., Christenson, S.C., and Schlottmann, J.L., 1989, Ground-water-quality assessment of the Central Oklahoma aquifer, Oklahoma-- Analysis of available water-quality data through 1987: U.S. Geological Survey Open-file Report $88-728,80 \mathrm{p}$.

Srodon, Jan, 1984, X-ray powder diffraction identification of illitic materials: Clays and Clay Minerals, v. 32, p. 337-349. 


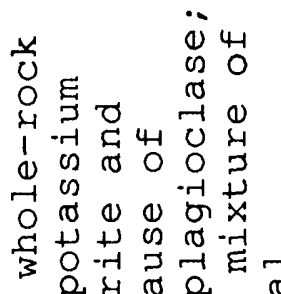

$\Omega$ \& $0 \Omega$ तo

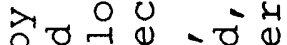

읻요 :

$\nabla$ तो 0 का $x-r$

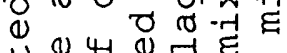

$+0$

है

न्न मे 0 म्न म्न त.

+0 U O

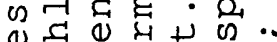

(1) 0 O

(2) 10 E 10 म

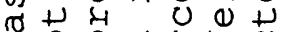

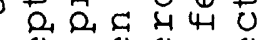

(1) 100$)$

1)

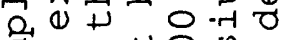

है +00

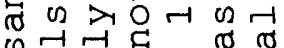

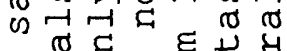

$\checkmark$ मे

00 मे लि

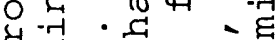
है

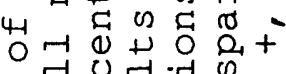

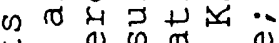

$\pm 40$

(1) 0 म $>00$

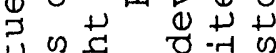

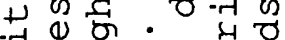

¿ 0 -

थ E (1) 110 O

C $3+$ है

○ ठ

U G

$4 \Omega$ ज? : के ते

○ 4 व

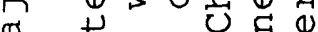

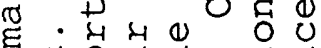
द 0 ரि

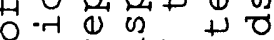

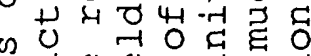

(1) त 10 (1) 0 G

(1) मे मे 4 मेन्न ठ

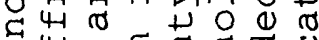

तै 4 ह ב

ठำ

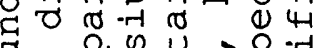

तो ल थ प्र : म

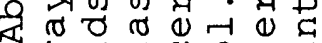

मे

..

-

每

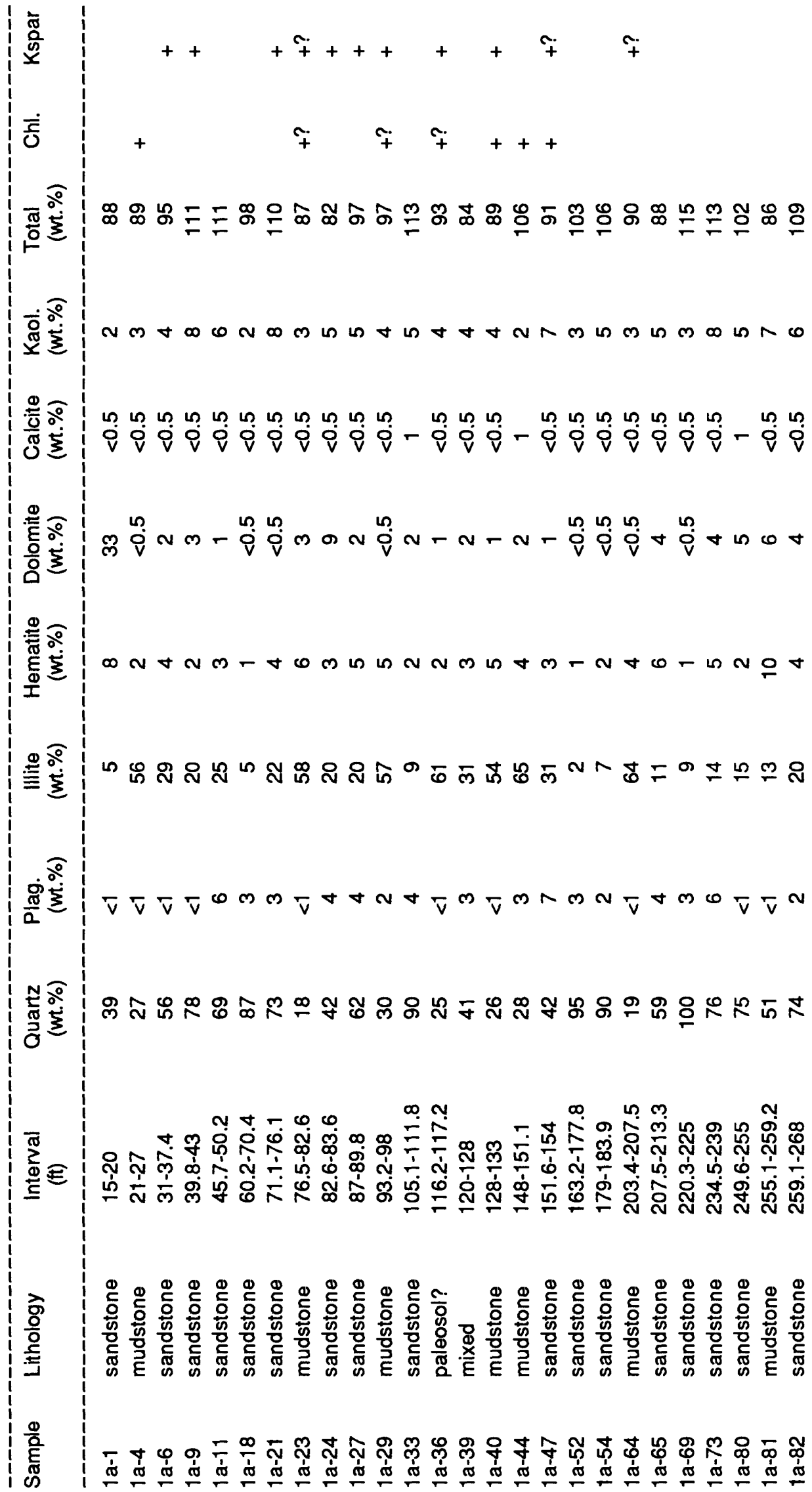




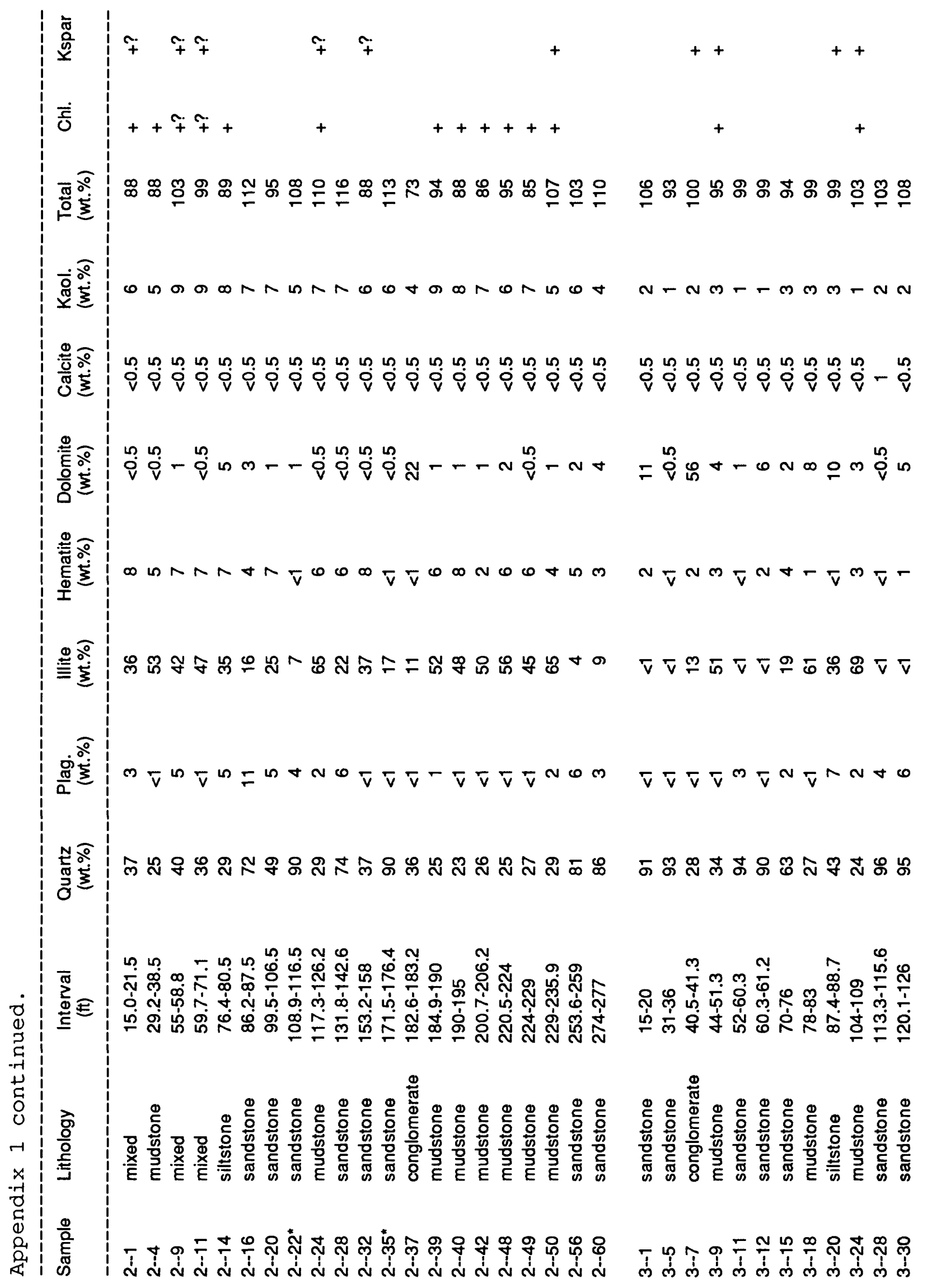




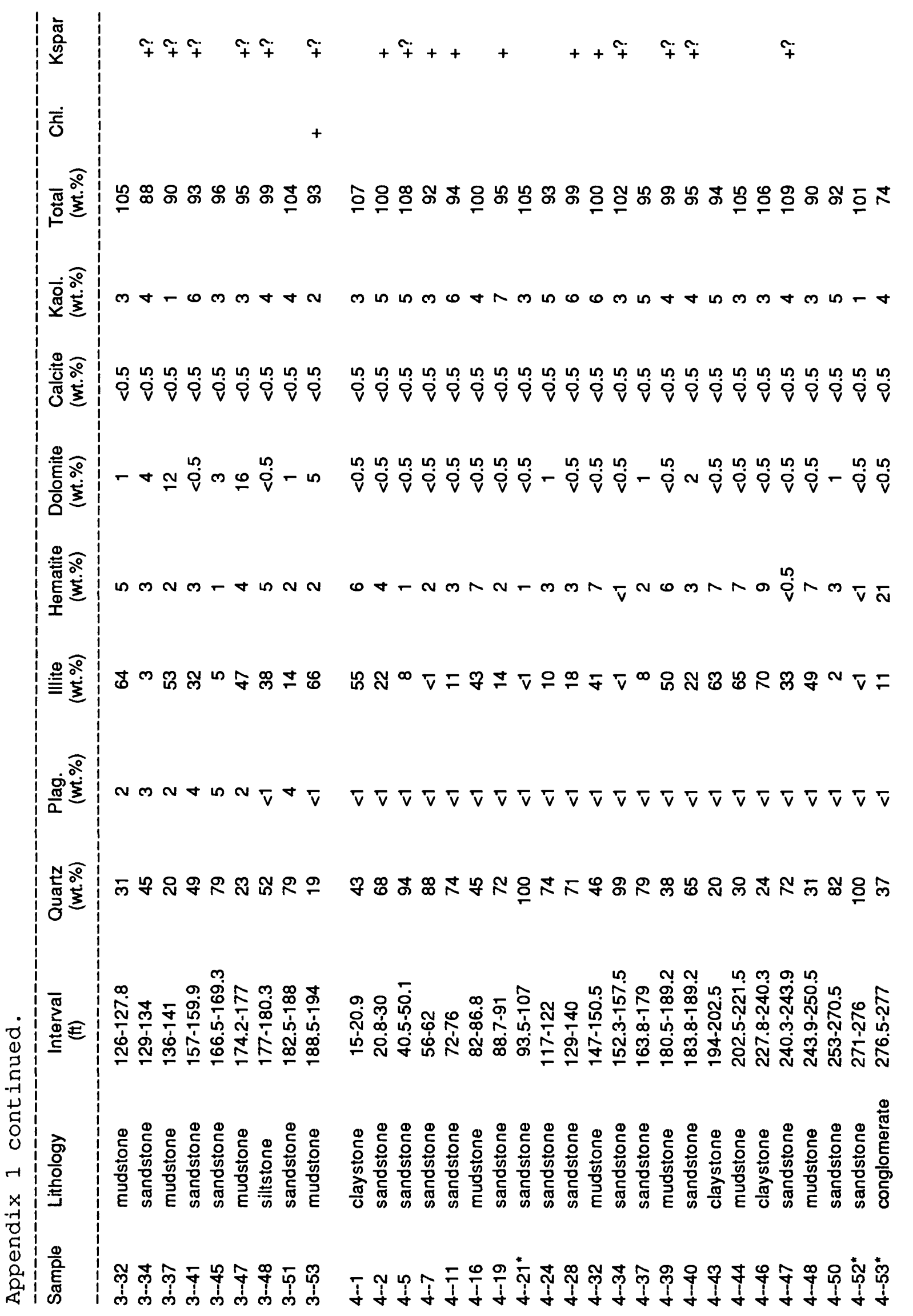




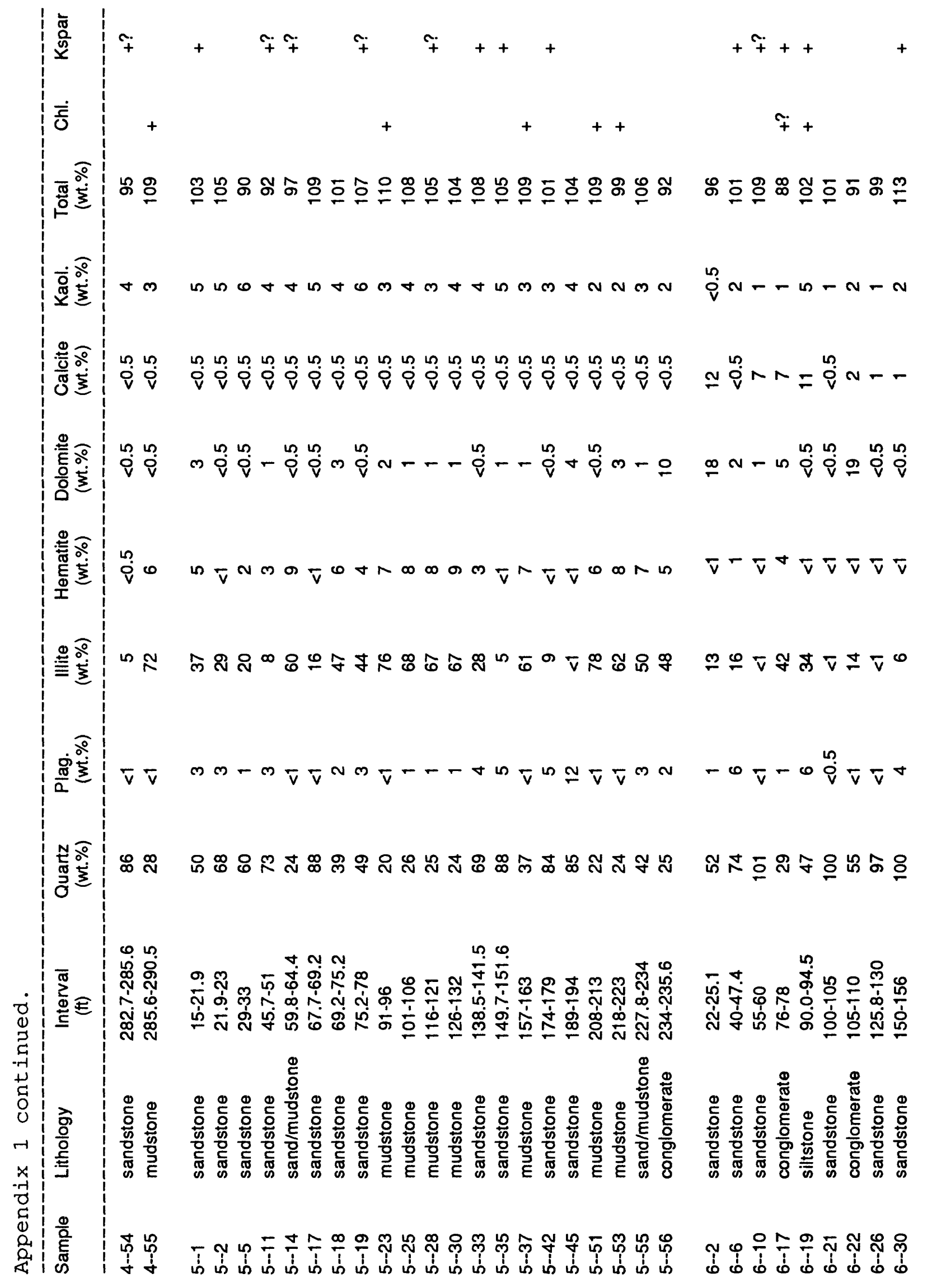




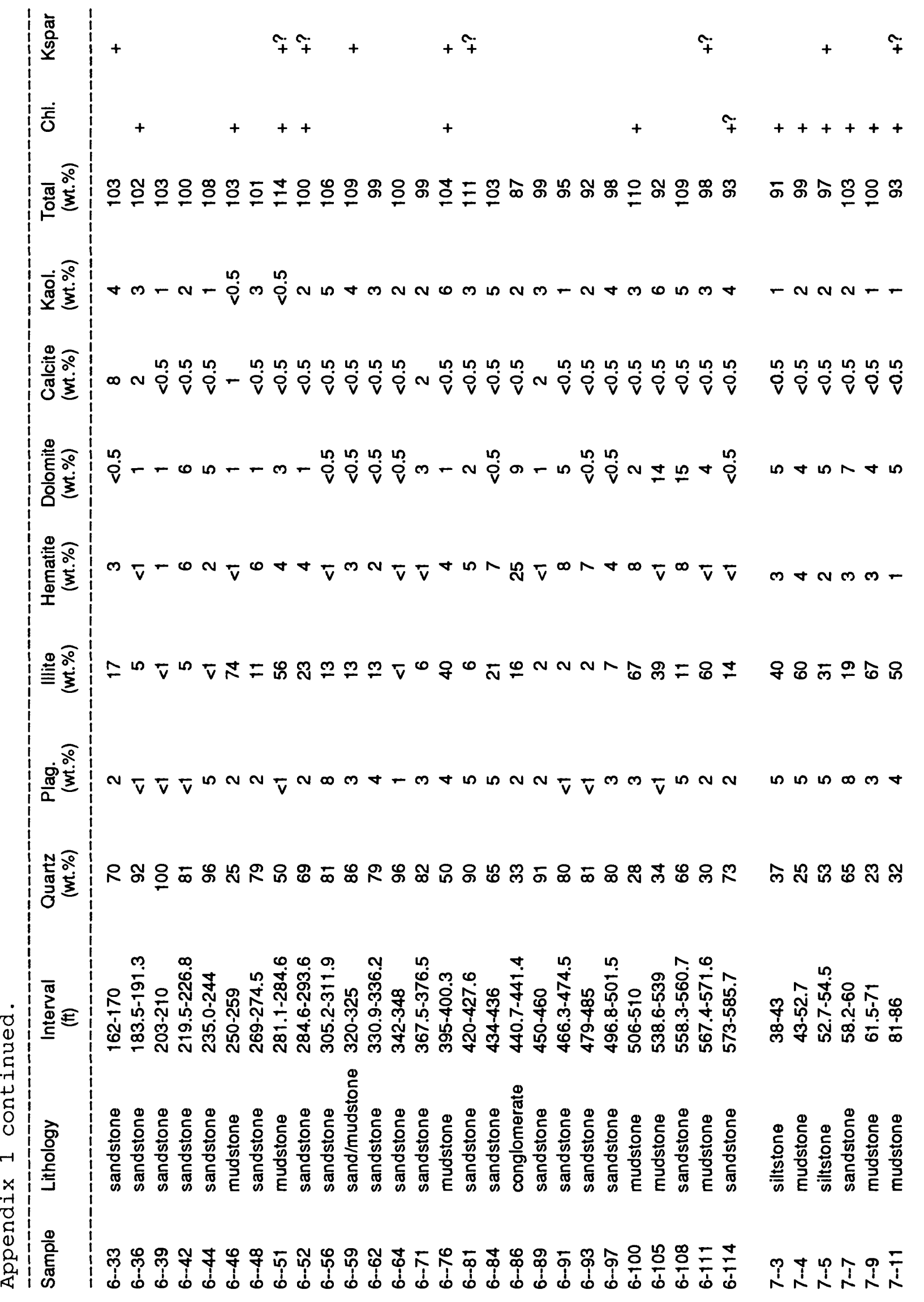




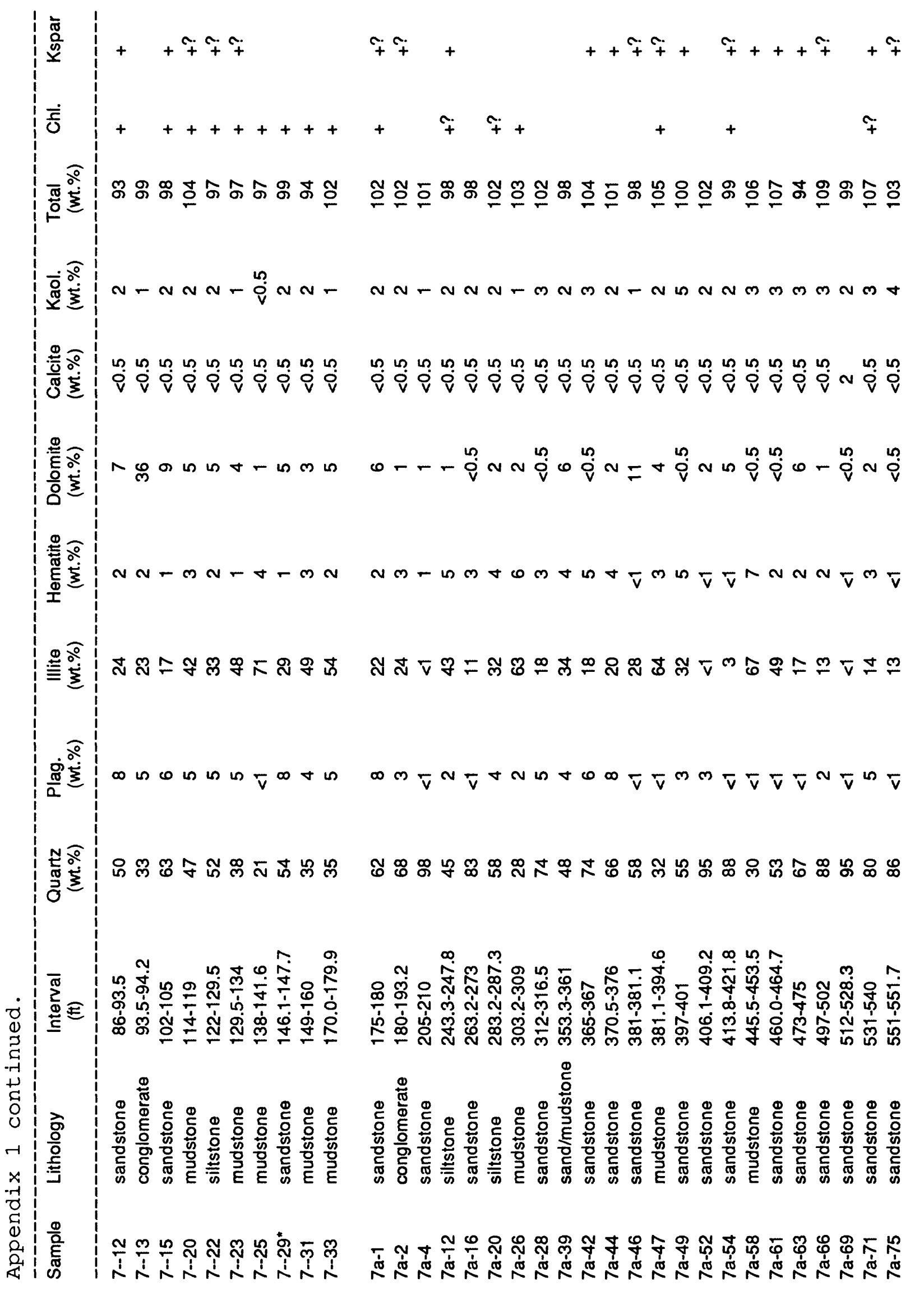




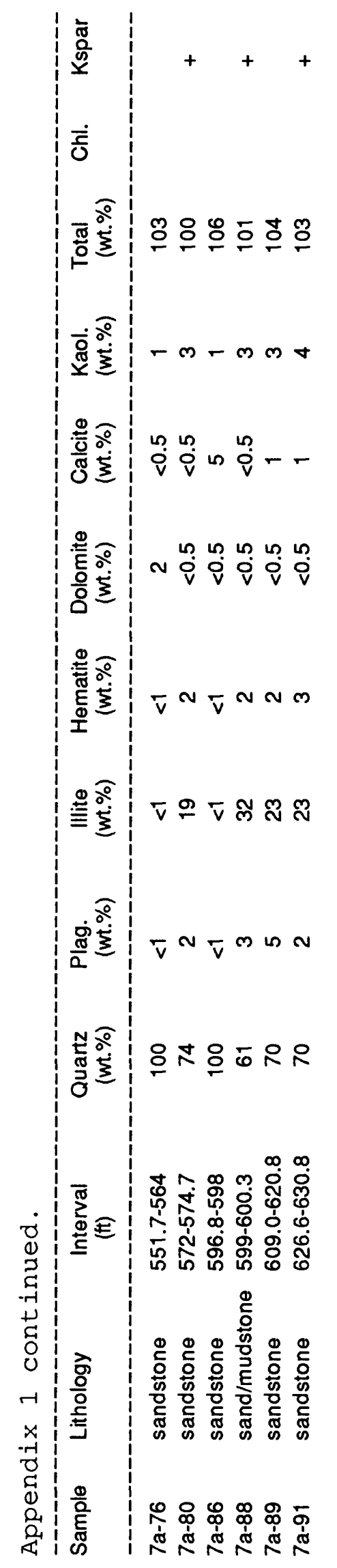




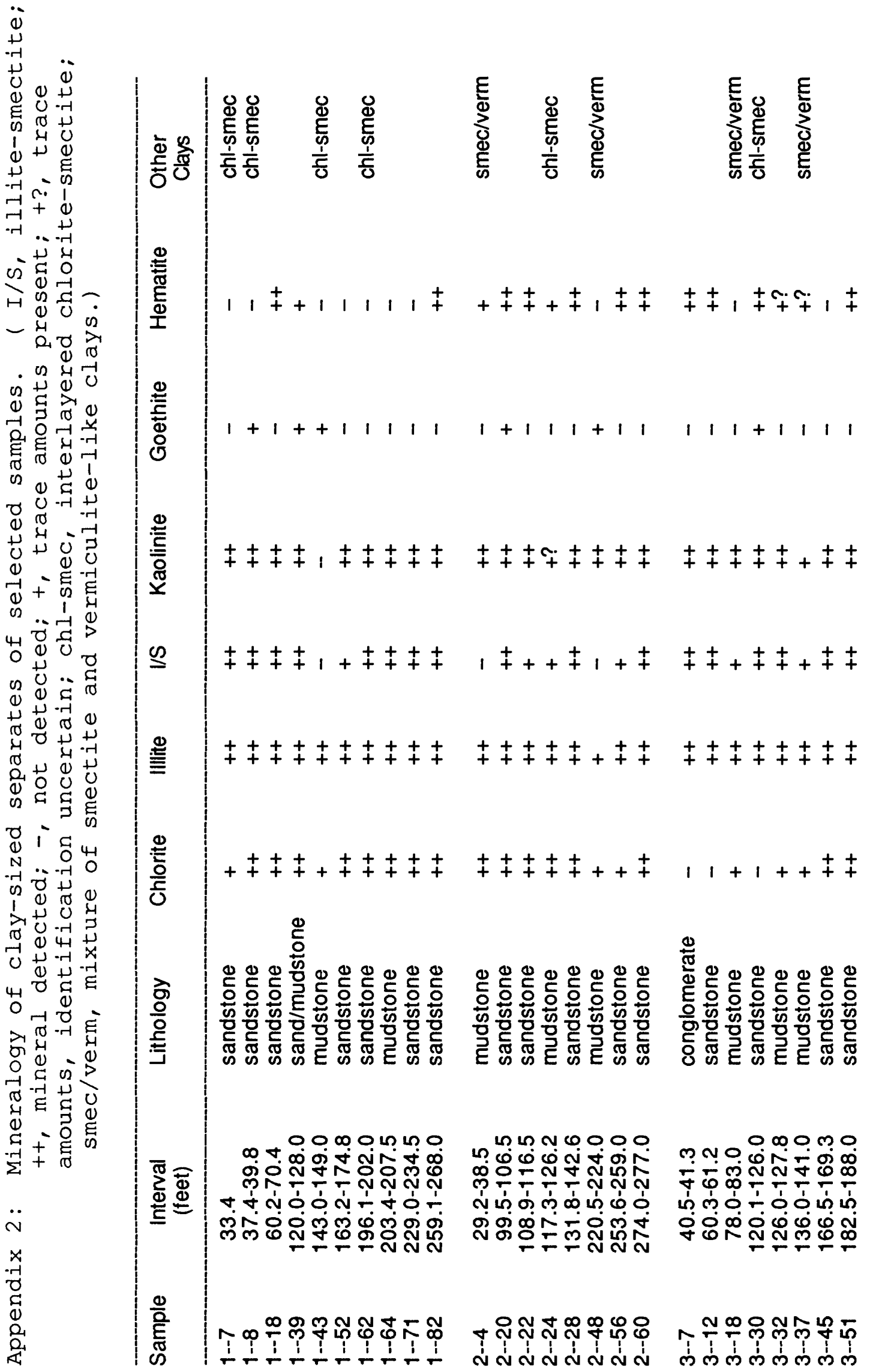




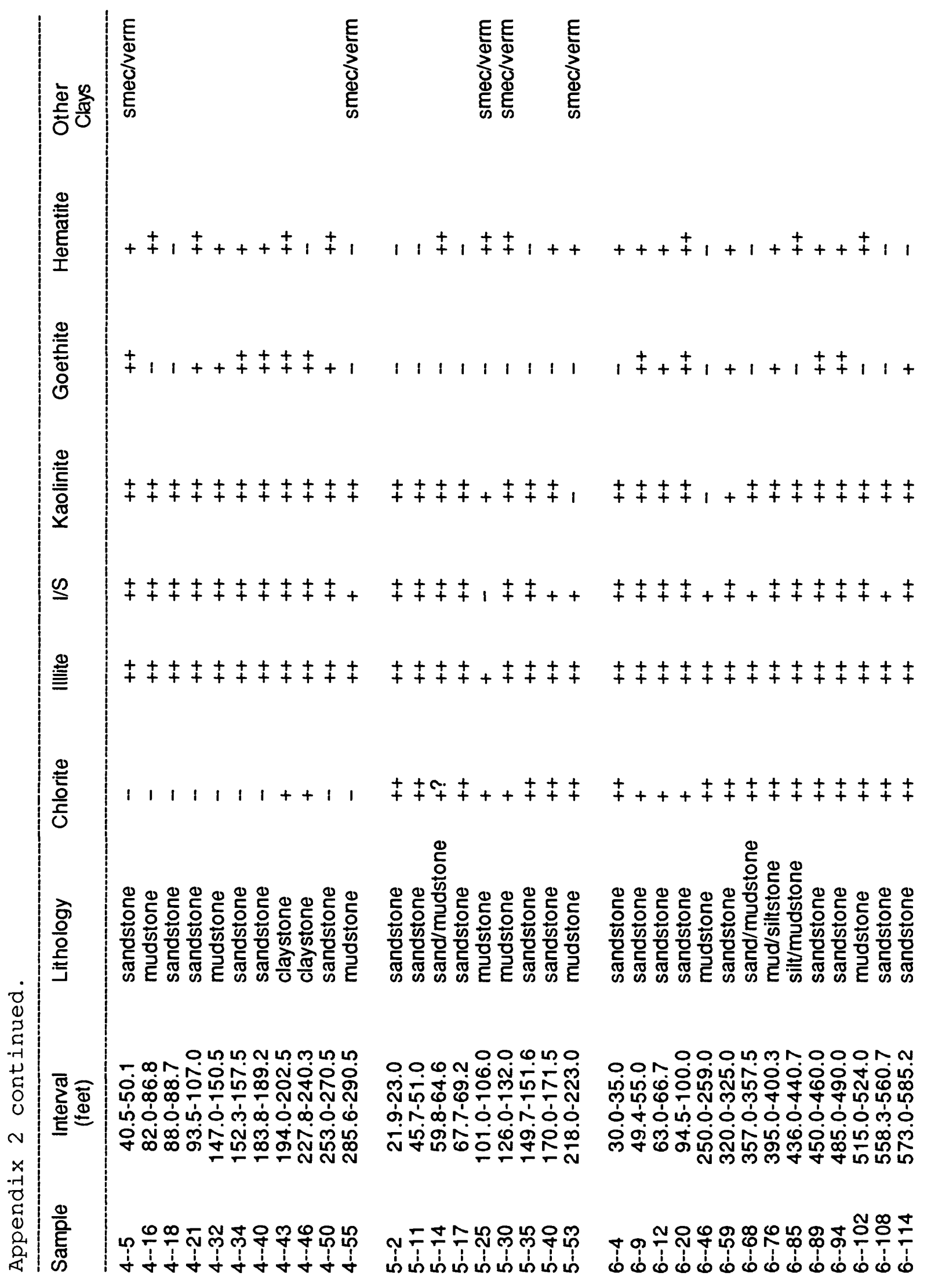




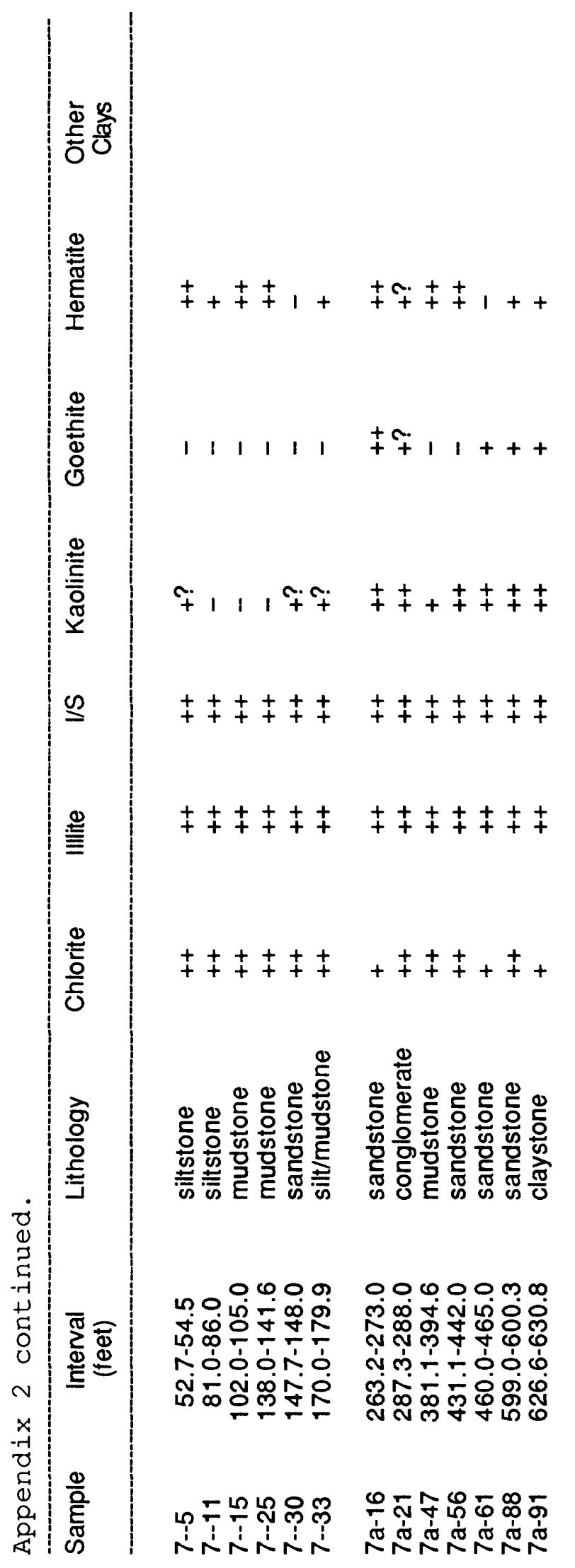




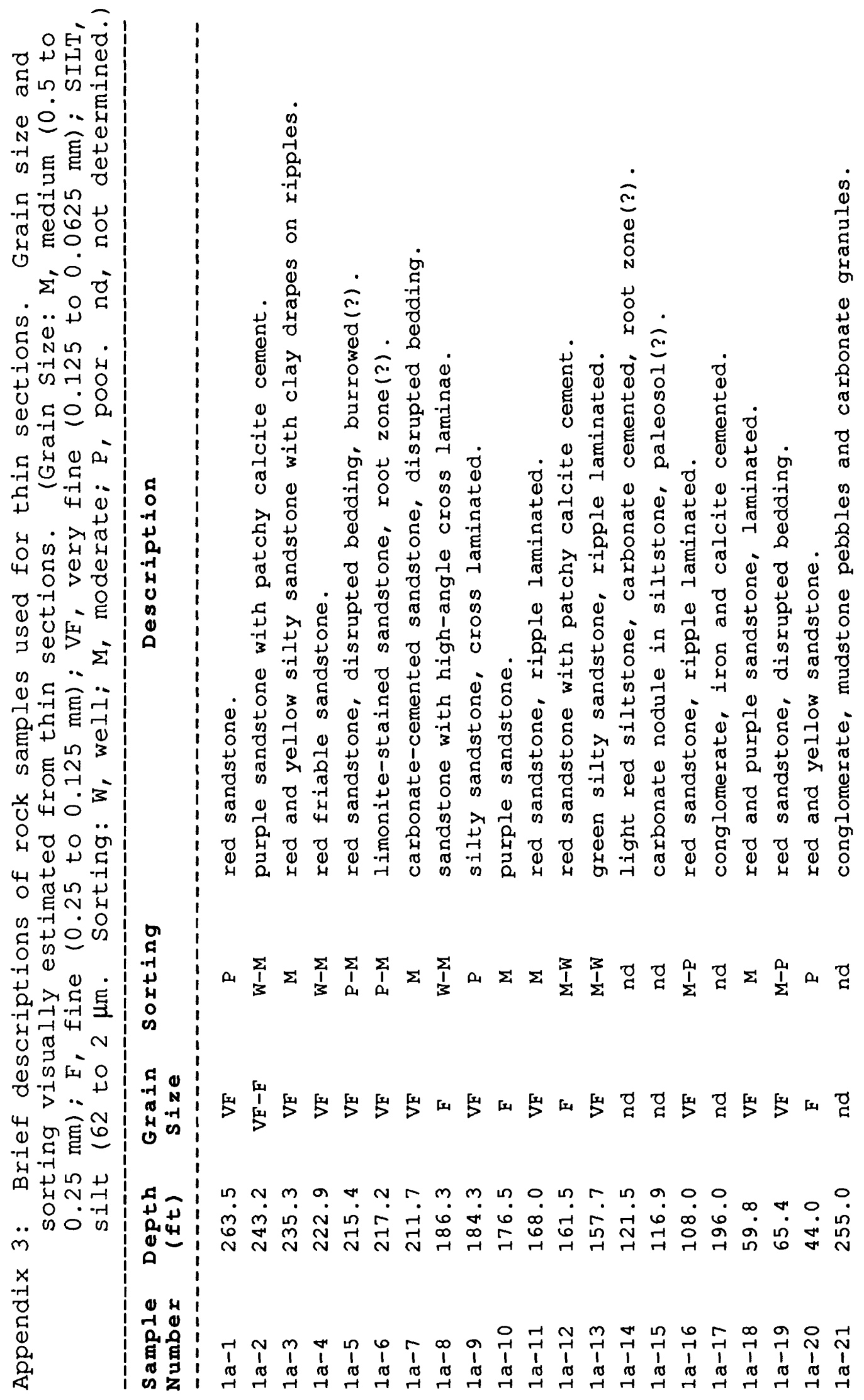




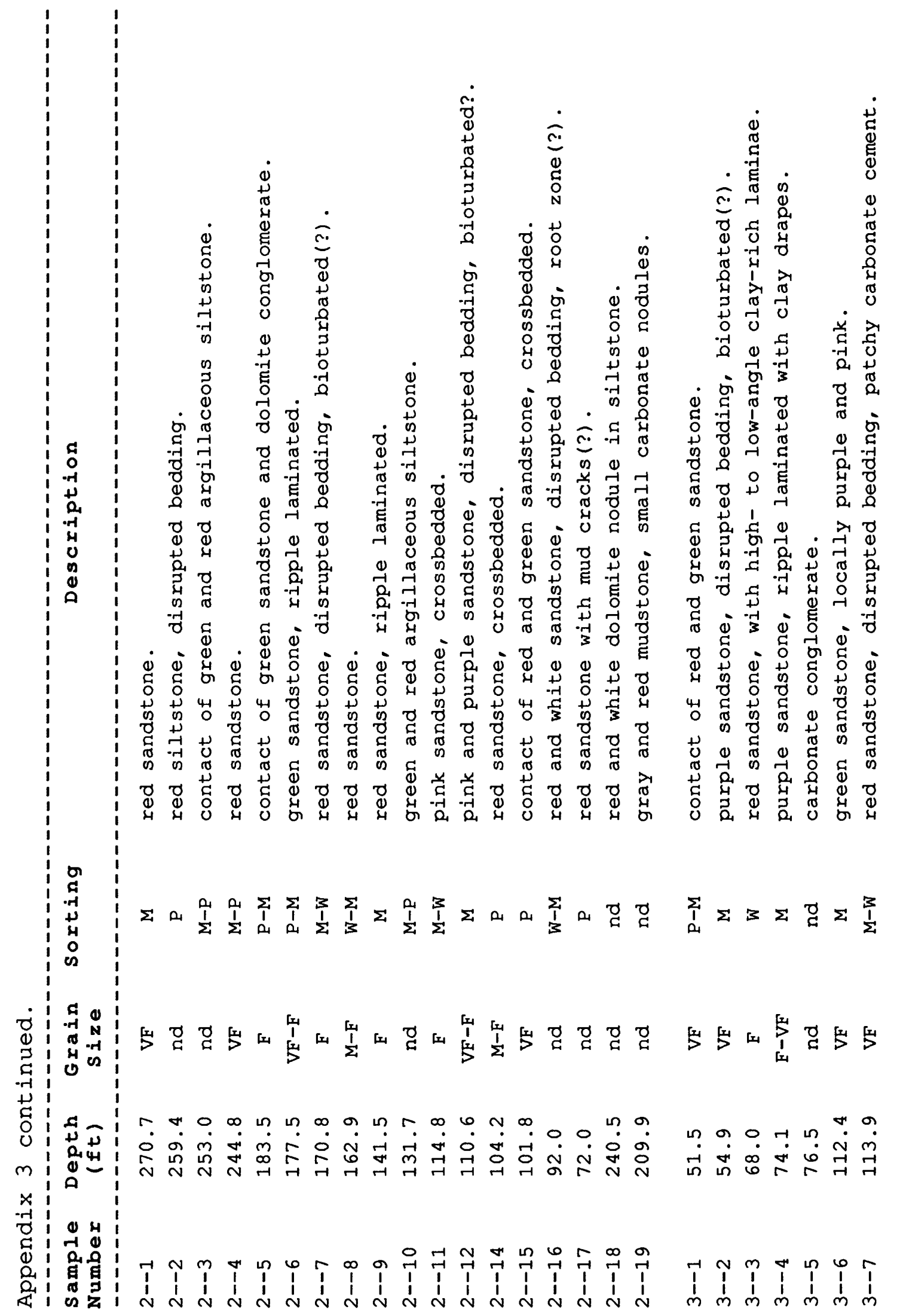



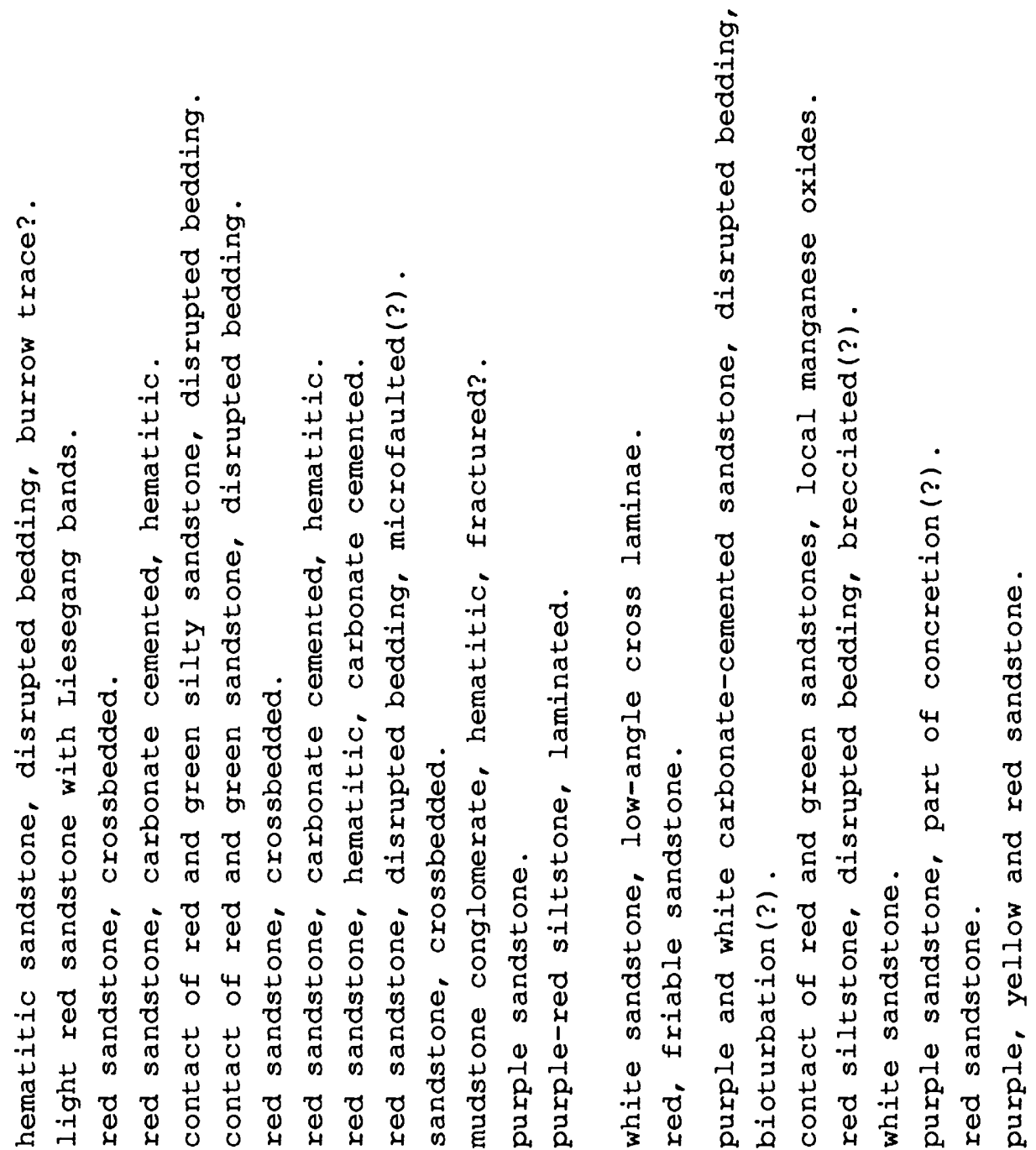

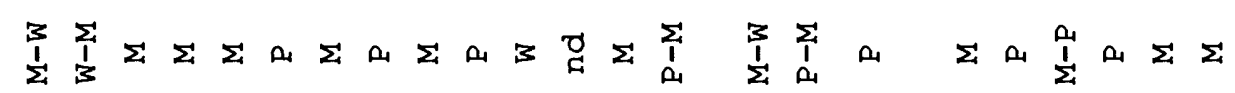

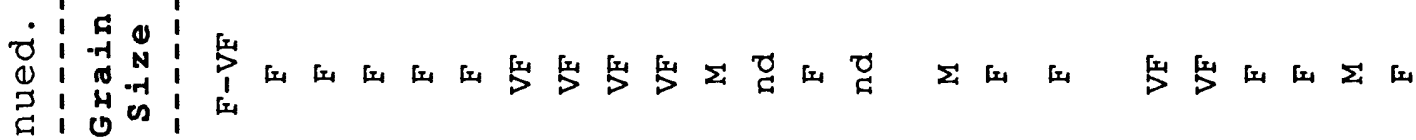

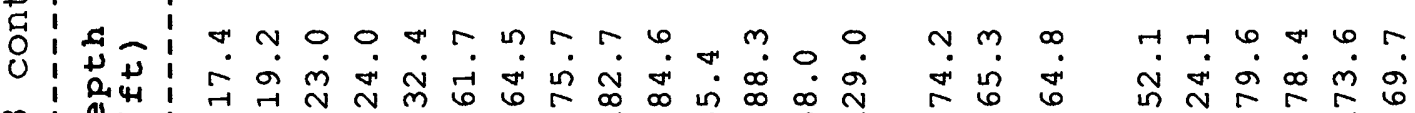

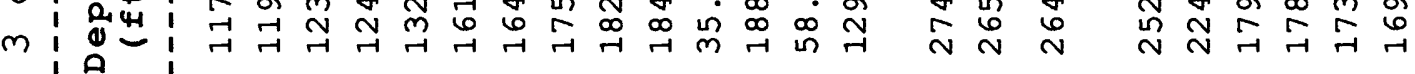
$x$

न

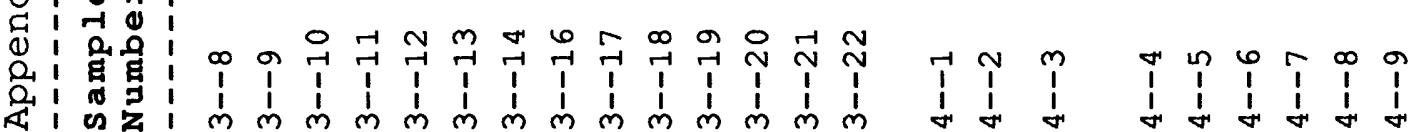




$$
\begin{aligned}
& \text { - } \quad \dot{a}
\end{aligned}
$$

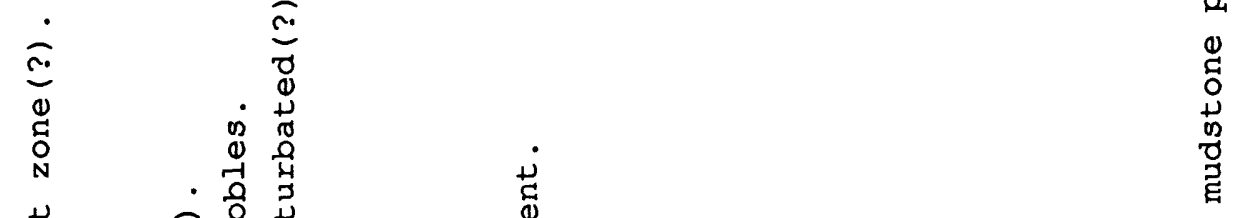

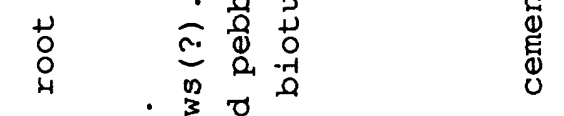$$
\dot{0} \dot{0} \text { व }
$$$$
\text { ก. }
$$$$
\text { ช }
$$

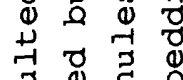

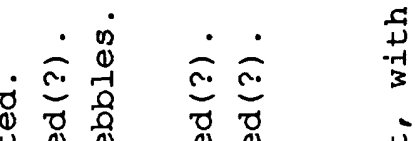

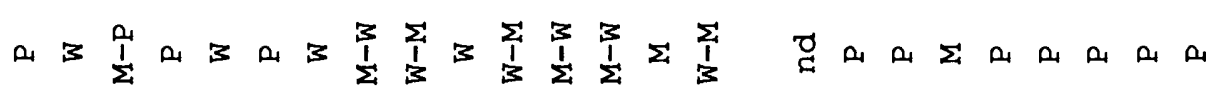

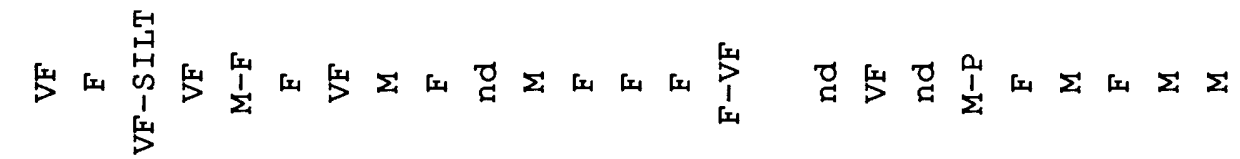

C: 1,1

? $\infty$.

茎

$m: \frac{1}{a}$

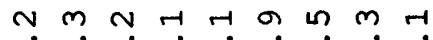

,

(1 1 1

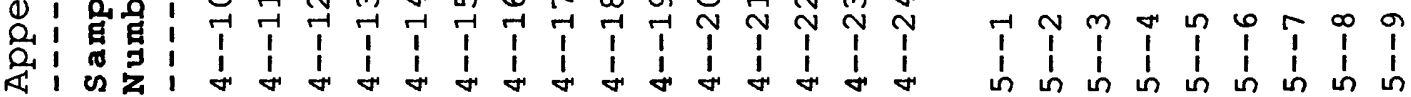




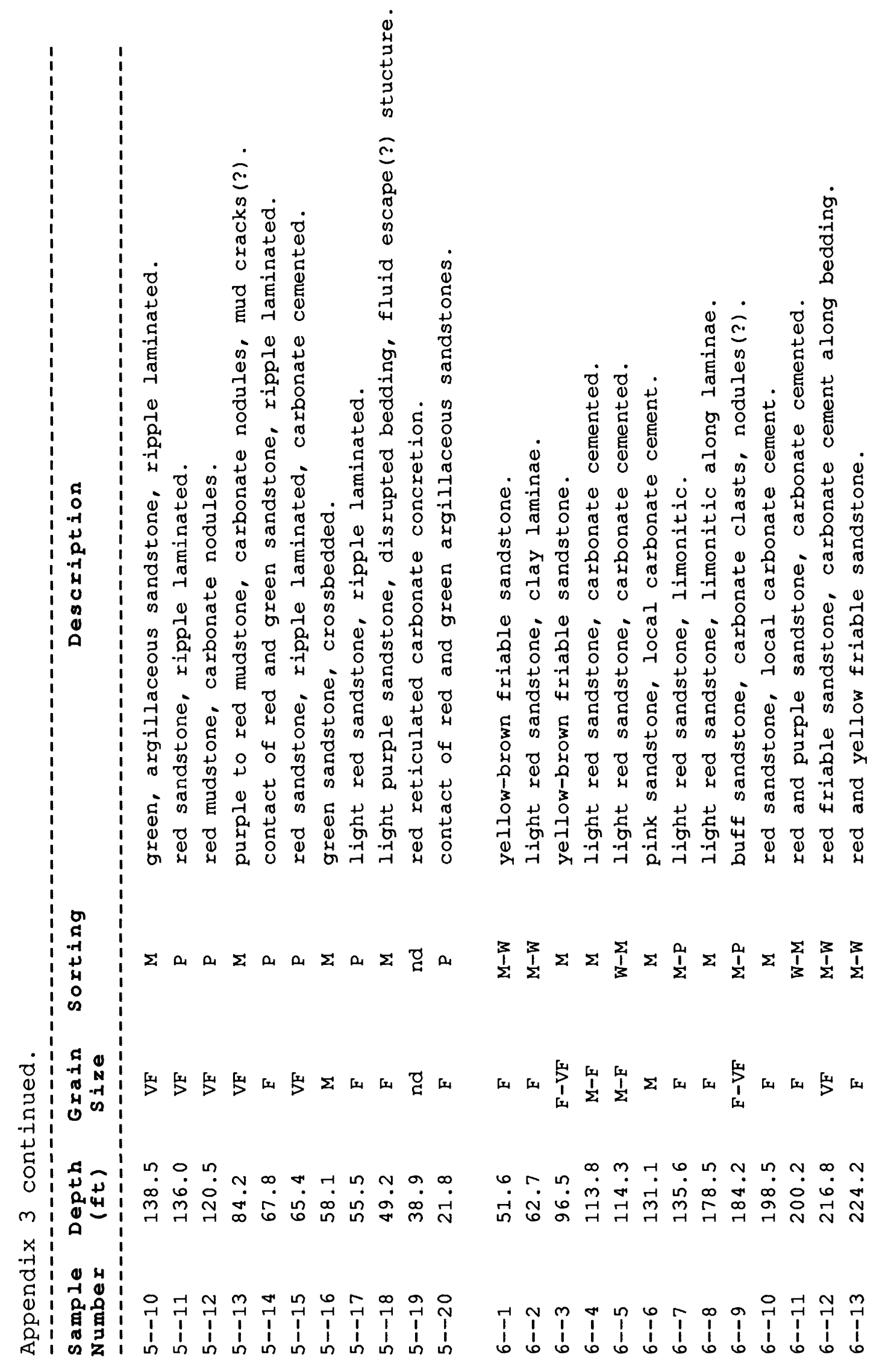




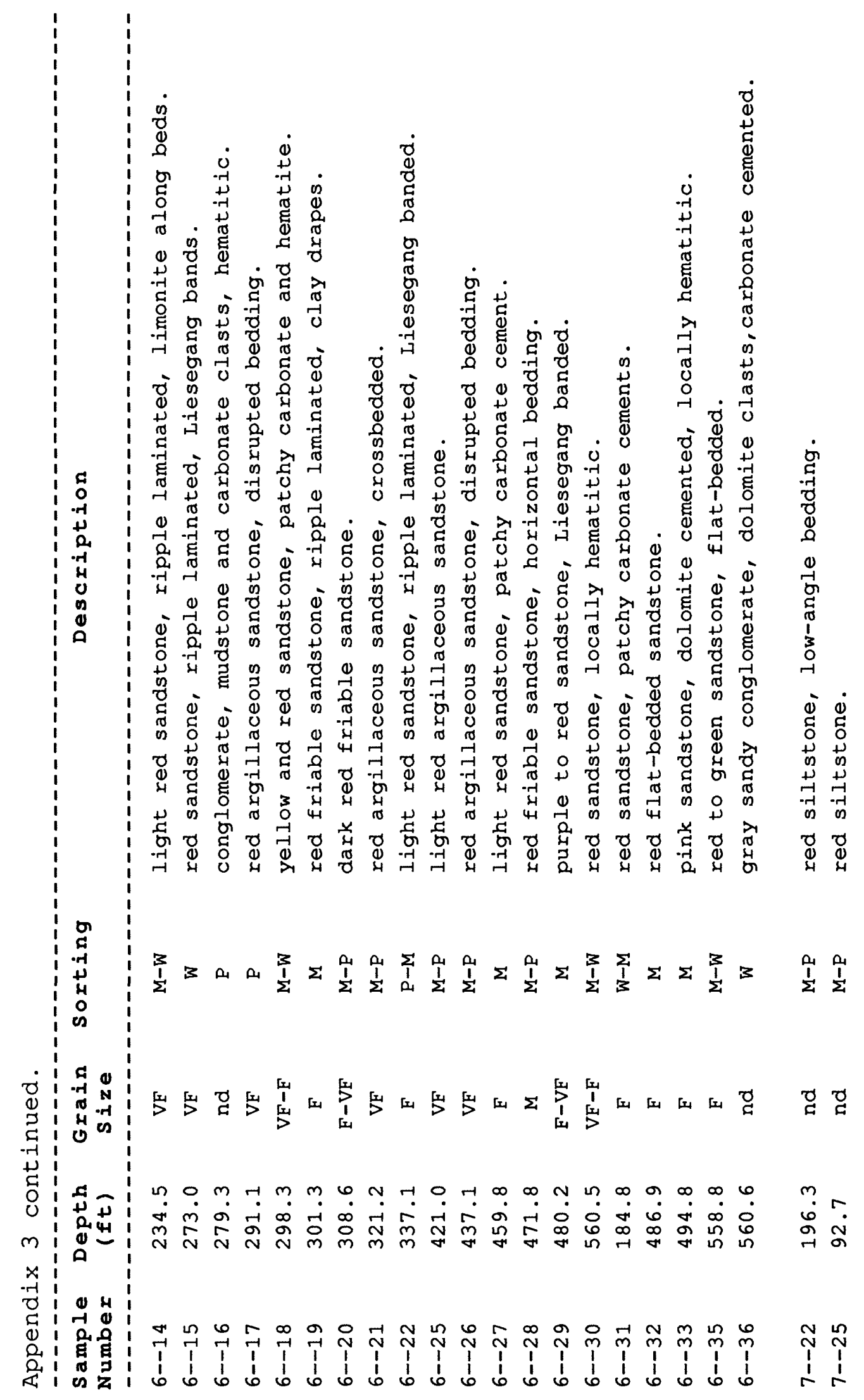




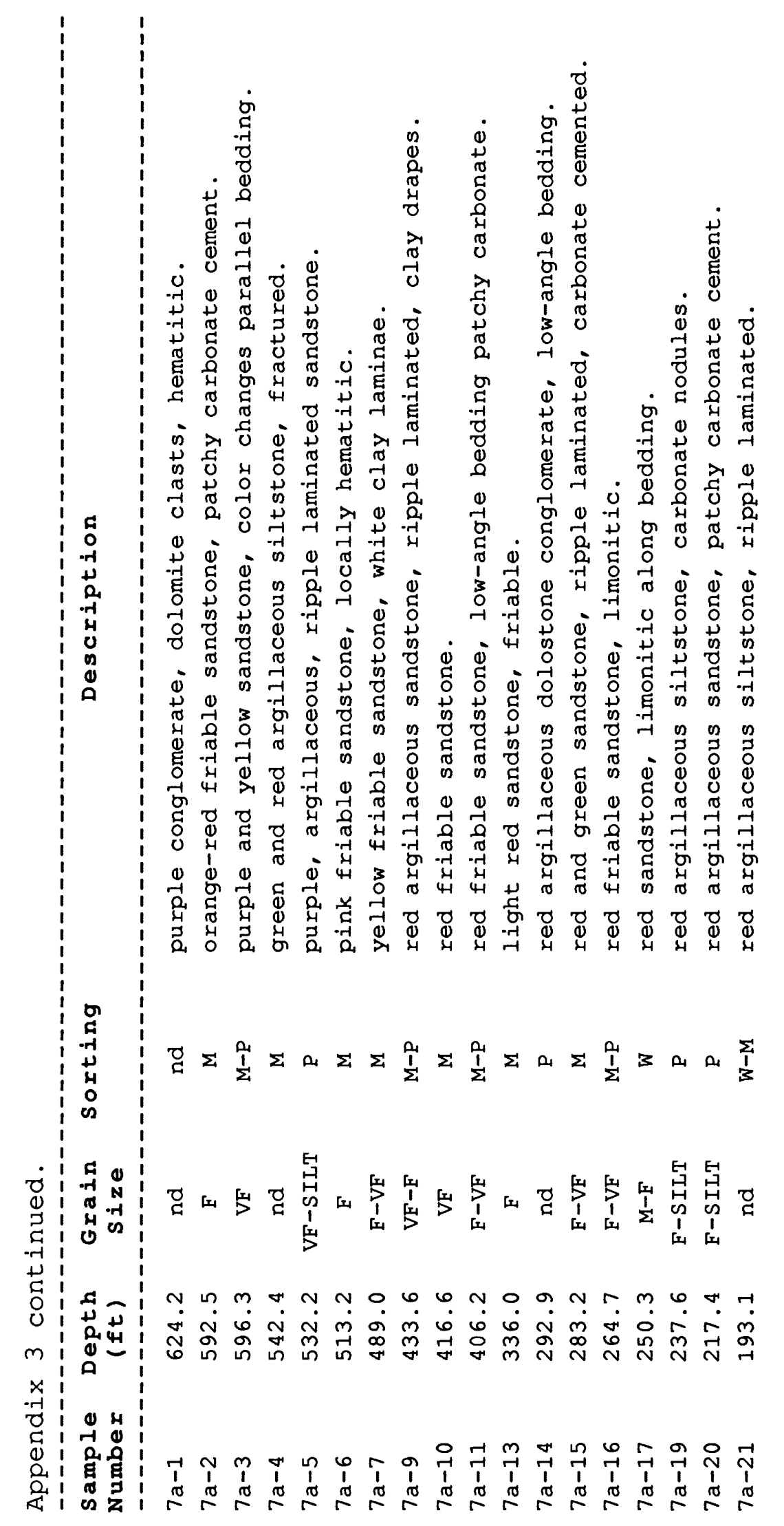



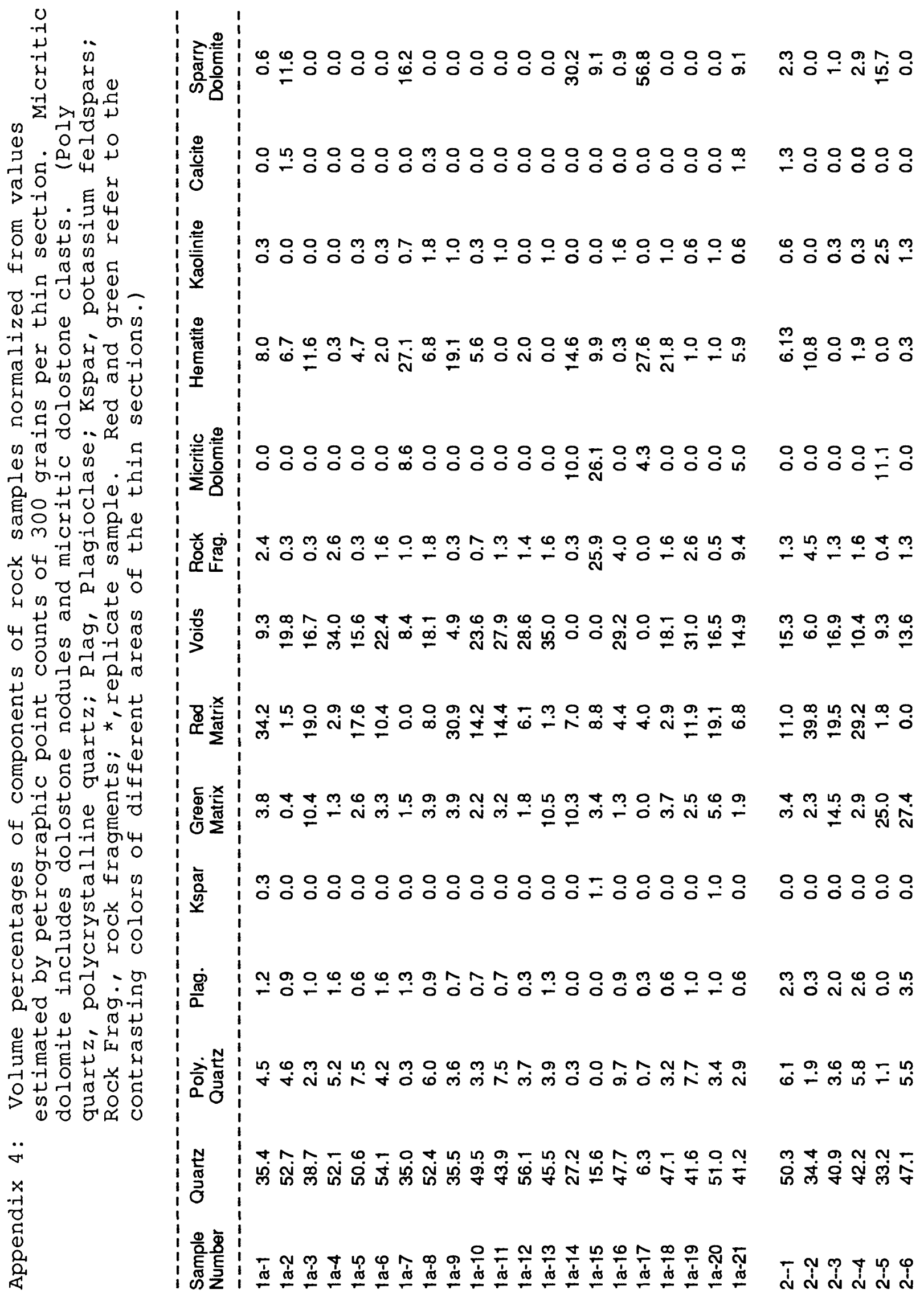
$0 m \infty 0 m-000 n-1$

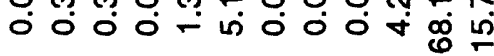

000000000000

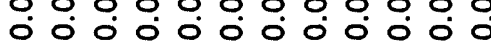

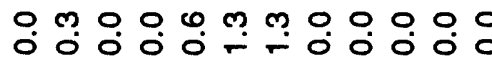

ก

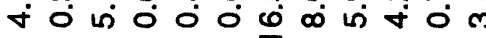

0000000000000 ०000000000

๑ M O 品 0 \%

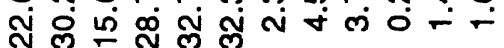

$\infty \circ \forall-\infty \circ \omega \sigma m \forall \hat{~ n ~}$ लं 守

a m ตั엉 웅 웅 웅 웅

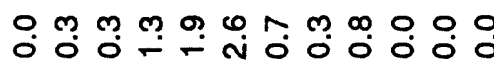
ช

O

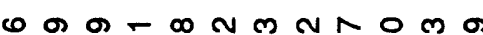
ழ

O 오

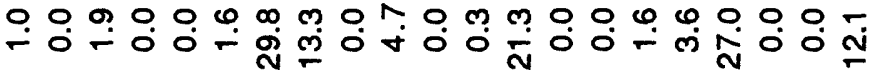

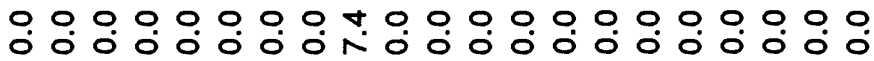

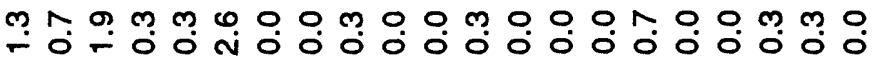

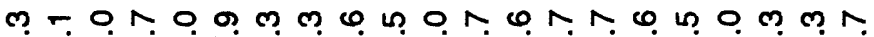

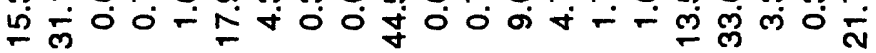

웅 웅웅영

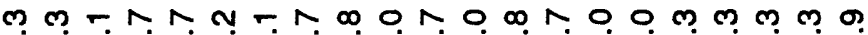

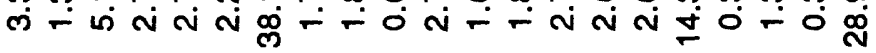

우 0 ด

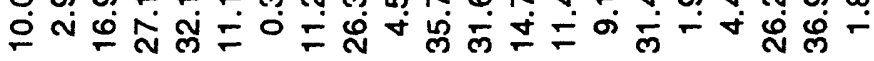
舟 Ғ ஸ่

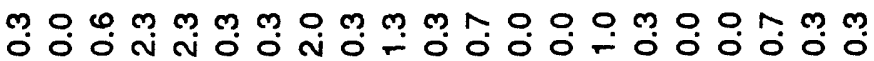
ம ल

กิ 年守 ヘิ่<smiles>[BH2-][BH2-]</smiles>

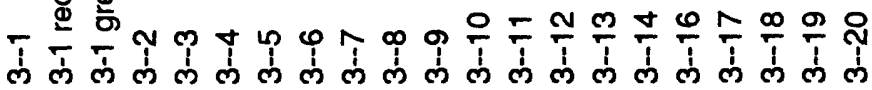




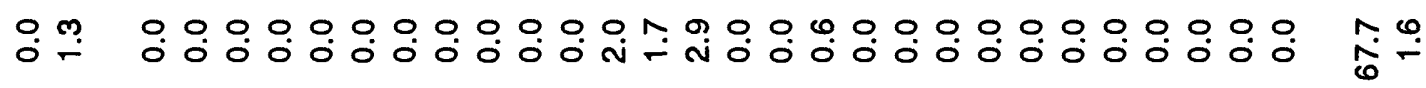

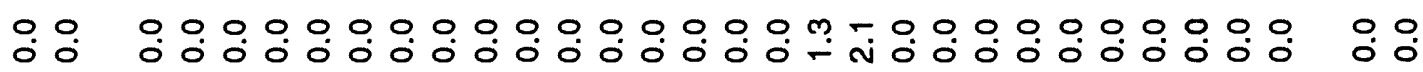

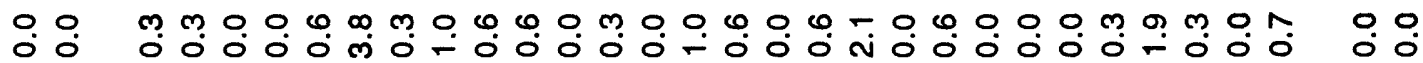

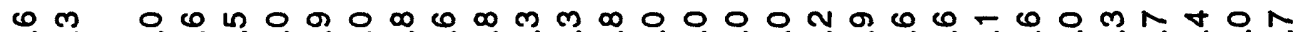

ก

0

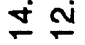

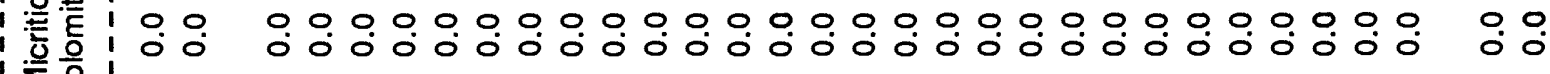

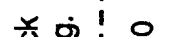

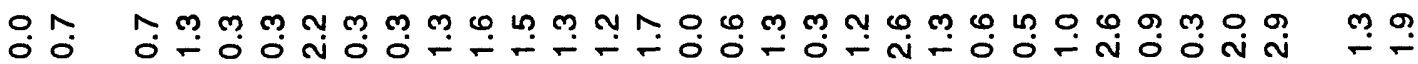

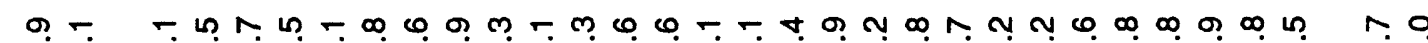

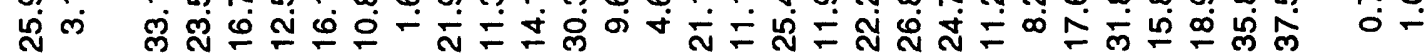

栗

舟

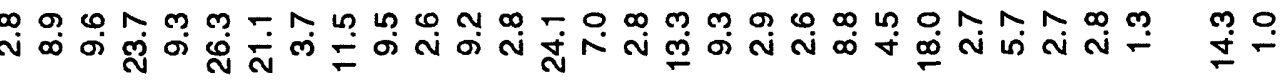

으

m m m $9000 \omega-0$ t

$\stackrel{\circ}{\circ} \stackrel{0}{0}$

○ -

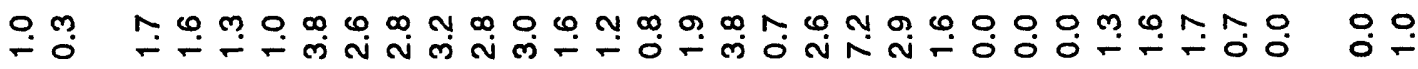

aN 6 t

$\stackrel{\circ}{\circ} \stackrel{0}{-}$

$\dot{\omega}$ ம்

ๆ

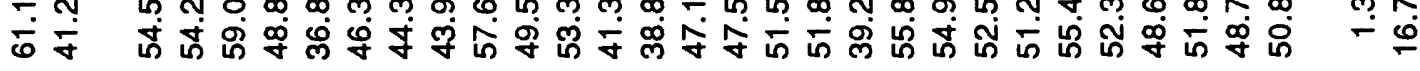


m-nomonmm m m

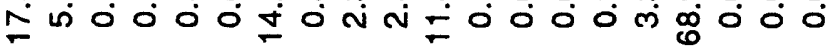

00000000000000000000

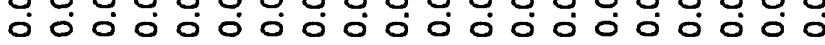

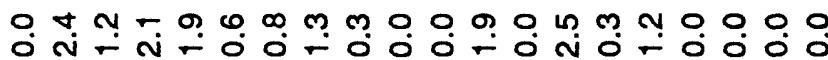

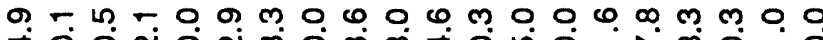

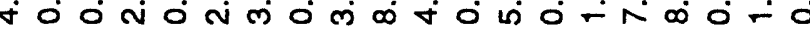

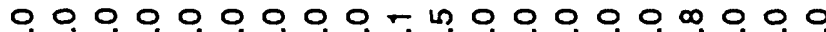

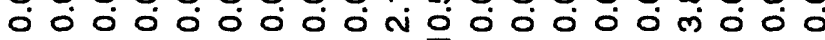

- nat na- 0 - 0 o om namono 过 ம் $\dot{\forall}$ ம

00 น

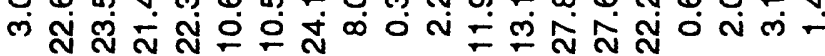

ON

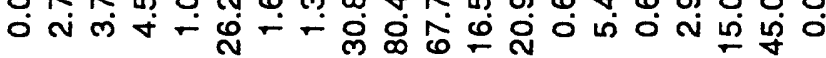

$\forall \infty ก \wedge 0 \%$ ก ○ัN

人 ลัก

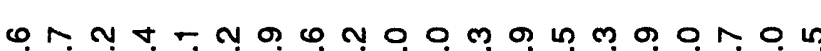
○ัง

\%m 00 \%

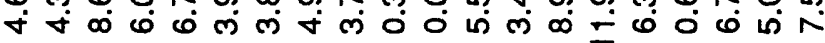
$\forall \sim 0$ \%

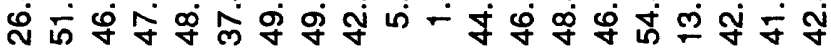

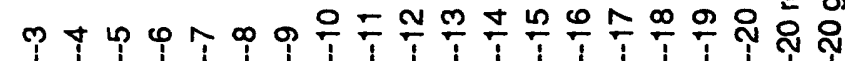

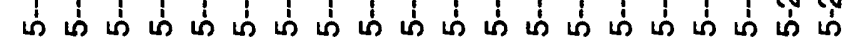

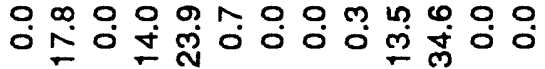

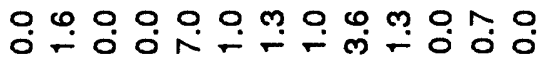

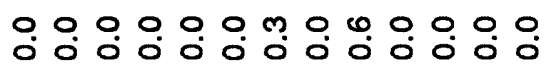

ก ก m

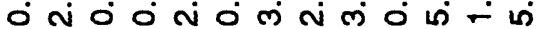

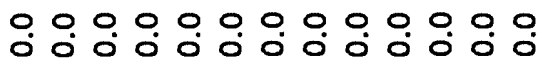
우웅 영 웅

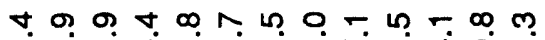

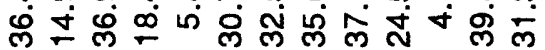

읍. - คั

$000 \% m$ ต $\because ّ$ ก

붕우

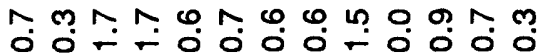

m

$\infty$ n $n=\infty$ n $\forall$ n $0.00 \%$ m กิ่

- 
o o- - o on

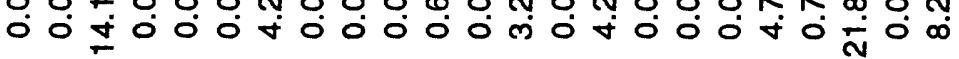

000000 m 0 m 00 m 00000000000

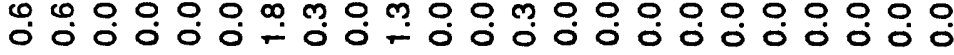

m 0 웅

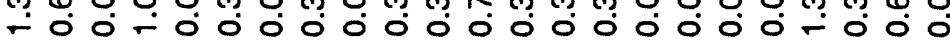

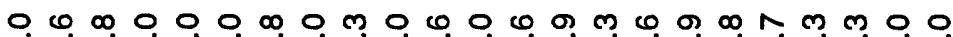
O

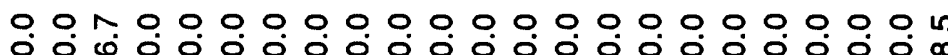
○ 0 î 长

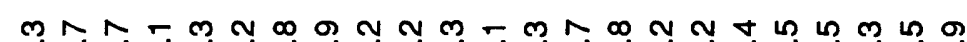

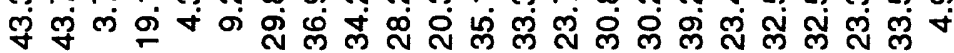

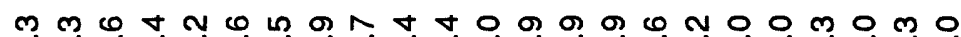

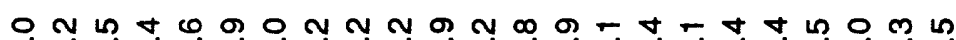
ल लं

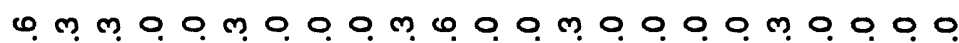

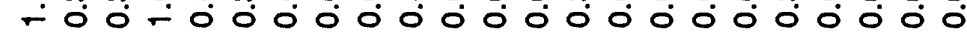

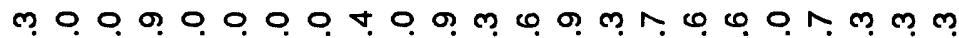

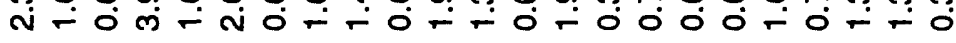

$\stackrel{1}{2} 1$

表: N

- 1 ते त्र

$+1$

द

0

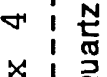

$x: \frac{0}{0}$

ठ

(1)

宸:

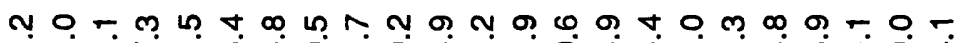

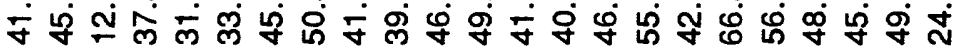<smiles></smiles>

ษ ถ่ ஸे

웅웅 웅융유유유융

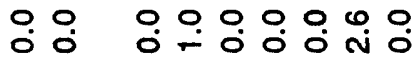

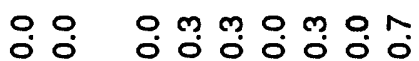

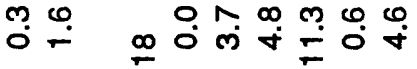

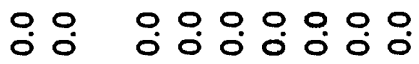

†ั

$\infty$ m.

○ึ

กึ่

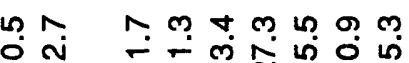

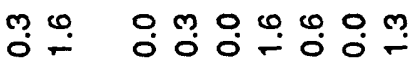

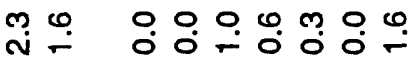

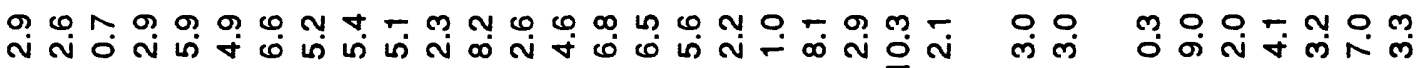

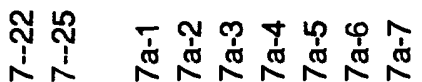


$000 m-000 N m$

苋赑

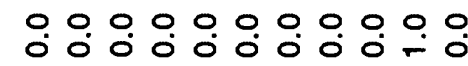

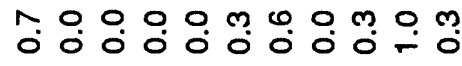

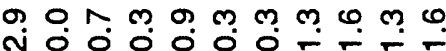

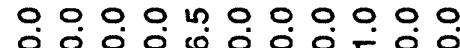

용 m mo N m

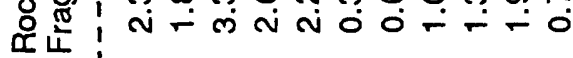

i.

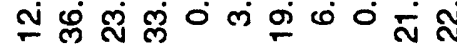

0 0 - $m$ o n $n-\ln \infty$

ழ্ं

แก ก $m$ ก

هั

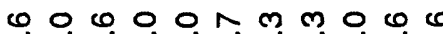

$-0-0000 \div 00$

OtNOMmUNMUm 4. 40.000 .0010

o

כ

究

: 100

O I

0 i

- N

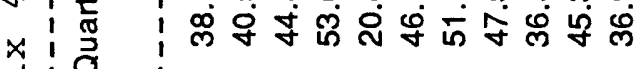

$\rightarrow$ i

\% 1

(1)

年

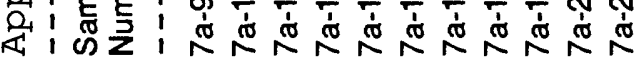

